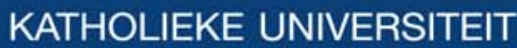 \\ EUYEN
}

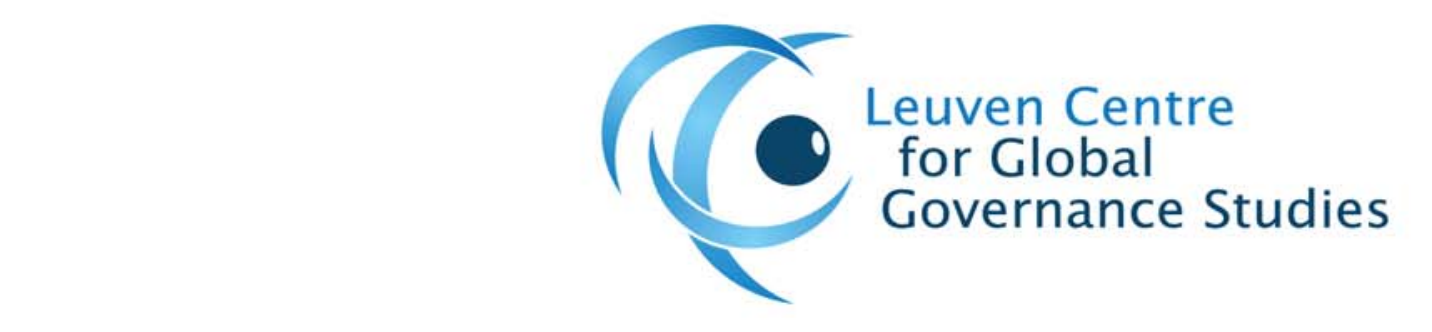

Working Paper No. 8 - January 2008

The Phenomenon of MultileVel Regulation: InTERACtions BETWEEN GLOBAL, EU AND NATIONAL REgULATORY SPHERES TOWARDS A RESEARCH AGENDA

Ramses Wessel - Jan Wouters

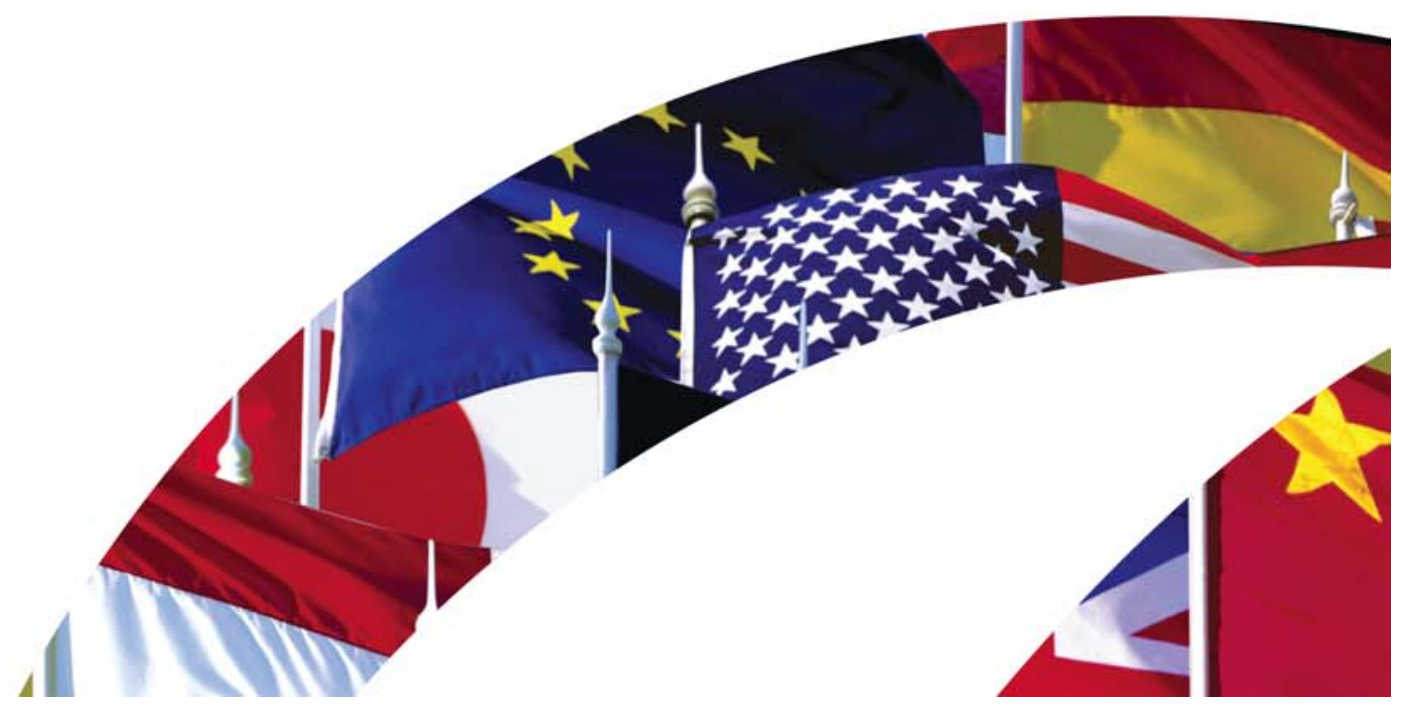




\title{
The Phenomenon of Multilevel Regulation: Interactions Between Global, EU and National Regulatory Spheres TOWARDS A RESEARCH AgENDA
}

\author{
Ramses Wessel - Jan Wouters
}

\begin{abstract}
:
Rules are no longer merely made by states, but increasingly by international organizations and other international bodies. At the same time these rules do impact the daily life of citizens and companies as it has become increasingly difficult to draw dividing lines between international, EU and domestic law. This contribution introduces the notion of 'multilevel regulation' as a way to study these normative processes and the interplay between different legal orders. It indicates that many rules in such areas as trade, financial cooperation, food safety, pharmaceuticals, security, terrorism, civil aviation, environmental protection or the internet find their origin in international cooperation. Apart from introducing multilevel regulation on the basis of a number of examples, the authors try to set out an agenda for further research, including legal and non-legal approaches.
\end{abstract}

Key words: multilevel, international organizations, legitimacy, legal orders, international rules

\section{Authors:}

Ramsel Wessel is professor of the Law of the European Union and other International Organisations at the Centre for European Studies of the University of Twente.

Jan Wouters is professor of international law and international organizations at Leuven University and Director of the Leuven Centre for Global Governance Studies. He studied law in Antwerp and Yale (LLM 1990), worked as a Visiting Researcher at Harvard Law School and is Visiting Professor at the College of Europe and Kyushu University Law School. He has published widely on international and European law and is President of the United Nations Association Flanders-Belgium. 


\section{CONTENTS}

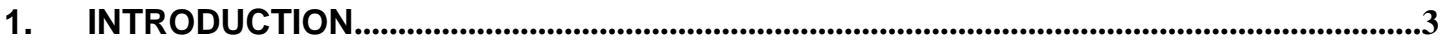

2. THE PHENOMENON OF MULTILEVEL REGULATION ....................................................5

2.1. THE INVASION OF INTERNATIONAL ORGANISATIONS.......................................................... 5

2.2. THE EXPANSION OF REGULATION: FROM GOVERNMENT TO GOVERNANCE …….................... 13

2.3. GOVERNANCE AND REgULATION AS A MULTI-ACTOR GAME …………............................. 17

3. THE RESPONSE FROM THE LEGAL COMMUNITY …..................................................20

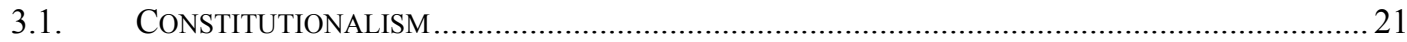

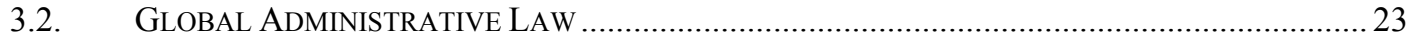

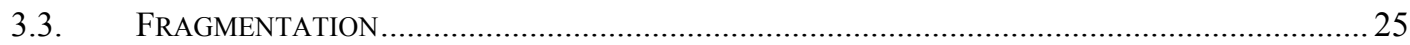

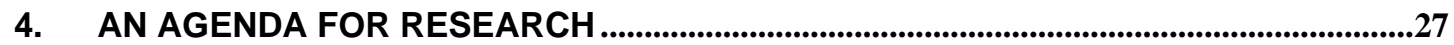

4.1. Combining Different Legal Perspectives: Accountability, Democracy,

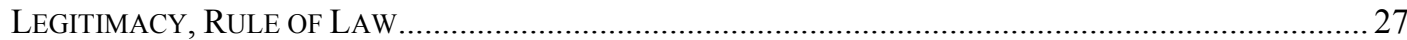

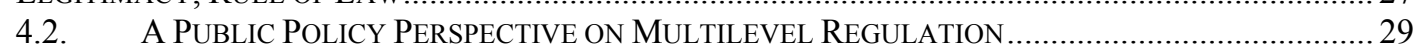

4.3. Rule Dynamics, Co-ORdination and Co-Operation in MultileVEl Regulation ..... 29

4.4. ACCOUNTABILITY, DemOCRACY and SOCIAL Justice In MultileVEL Regulation .......... 31

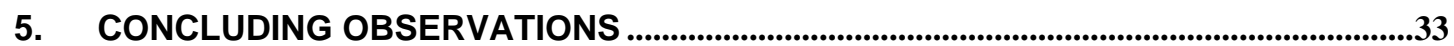




\section{INTRODUCTION}

Over the past decade globalisation and global governance have become central themes, not just in international relations and politics, but also in the study of international and national law. The reason may well be, as some observers hold, that "central pillars of the international legal order are seen from a classical perspective as increasingly challenged: the distinction between domestic and international law becomes more precarious, soft forms of rule-making are ever more widespread, the sovereign equality of states is gradually undermined, and the basis of legitimacy of international law is increasingly in doubt." Indeed, many of these themes feature in current research programmes. Domestic legal systems - traditionally by definition caught in national logic - increasingly recognise the influence of international and transnational regulation and law-making on their development. ${ }^{2}$ Legal scholars attempt to cope with the proliferation of international organisations and other entities contributing to extra-national normative processes. ${ }^{3}$

While the notion and consequences of globalisation are the subject of debate, common denominators seem at least to include a profound transformation of the traditional Nation State and the inability of sovereignty to protect the State against foreign interference. ${ }^{4}$ The proliferation of international organisations ${ }^{5}$ and the expansion of international law as well as the related need for national legal systems to implement ever more international rules are commonly considered to go hand in hand with globalisation. ${ }^{6}$ Apart from challenging some of the foundations of international law, globalisation raises questions in particular about to the negative effects it may have on the rule of law, democracy and legitimacy (infra, 4.1.).

$1 \quad$ N. Krisch and B. Kingsbury, 'Introduction: Global Governance and Global Administrative Law in the International Legal Order', EJIL, Vol. 1 2006, pp. 1-13, at p. 1.

2 For an analysis of the main trends see the research programme of the Hague Institute for the Internationalisation of Law (HiiL): http://www.hiil.org..

3 See K. Jayasuriya, 'Globalization, Law, and the Transformation of Sovereignty: The Emergence of Global Regulatory Governance', Indiana Journal of Global Legal Studies, Vol. 2 1999, pp. 425-255. In his book International Organizations as Law-makers (Oxford University Press, 2005) José Alvarez reveals that the role of international organisations in law-making not only increased, but also that international law is not always well enough equipped to handle this development. Cf. also D. Sarooshi, International Organizations and their Exercise of Sovereign Powers, Oxford: Oxford University Press, 2005. See earlier in particular J. Delbrück (ed.), New Trends in International Lawmaking - International 'Legislation' in the Public Interest, Berlin: Ducker \& Humblot, 1996; on the development of the (sub-) discipline of the law of international organisations in general, see J. Klabbers, 'The Life and Times of the Law of International Organizations', Nordic Journal of International Law, 2001, pp. 287-317.

4 A. von Bogdandy, 'Globalization and Europe: How to Square Democracy, Globalization and International Law', EJIL, Vol. 5 2004, pp. 885-906 at pp. 886-887.

5 On this phenomenon see N.M. Blokker and H.G. Schermers, (eds.), Proliferation of International Organizations, The Hague: Kluwer Law International, 2001.

6 A. von Bogdandy, supra, p. 889. 
The interactions between national and international legal spheres, including the European legal sphere for EU Member States, have intensified and gained increased visibility over the last few years. It is becoming ever more difficult to draw dividing lines between legal orders: international law is increasingly coming to play a role in national (and EU) legal orders, whereas national (and EU) legal developments are exerting a bottom-up influence on the evolution of the international legal order. ${ }^{7}$ In political science and public administration, the phenomenon of interacting and partly overlapping policy spheres is often referred to as multilevel governance. Two dimensions of this concept are particularly relevant to the present contribution. The first one, 'governance without government', points to the phenomenon that a number of public tasks are increasingly assumed and carried out by actors other than the classical government institutions of the Nation State (and its subdivisions). ${ }^{8}$ The second dimension, 'governance beyond the State', refers to the complexity of governance at distinct but increasingly intertwined levels. 'Multilevel' then refers to a variety of forms of decision making, authority, policy making, regulation, organisation, ruling, steering, etcetera, characterized by a complex interweaving of actors operating at different levels of formal jurisdictional or administrative authority, ranging from the local level, via the national level, to the macro-regional and global level. ${ }^{9}$ These phenomena involve important questions concerning the location of power, the sharing of responsibility, the legitimacy of decisions and decision takers, and the accountability to citizens and organisations in different national, sub-national and international settings. From a legal perspective, the interactions between global, European and national regulatory spheres lead to what one could refer to as the phenomenon of 'multilevel regulation'. ${ }^{10}$ We understand 'regulation' in a broad sense

7 On the phenomenon of what can be cautiously referred to as a new 'Europeanisation' of international law, see J. Wouters, A. Nollkaemper, and E. de Wet, (eds.), The Europeanisation of International Law: The Status of International Law in the EU and Member States, The Hague: T.M C. Asser Press, 2008 (forthcoming).

8 See for instance O. Treib, H. Bähr and G. Falkner, 'Modes of Governance: A Note Towards Conceptual Clarification', European Governance Papers, No. N-05-02, 17 November 2005, available at http://www.connex-network.org/eurogov/pdf/egp-newgov-N-05-02.pdf.

9 A classic is L. Hooghe and G. Marks, Multi-level Governance and European Integration, Lanham, MD: Rowan \& Little Field Publishers, 2001. In legal academic circles the notion has been picked up and applied, inter alia, by N. Bernard, Multilevel Governance in the European Union, The Hague: Kluwer Law International, 2002.

10 See R.A. Wessel, The Invasion by International Organizations. De toenemende samenhang tussen de mondiale, Europese en nationale rechtsorde [The Increasing Interrelatedness between Global, European and National Legal Orders], Inaugural Lecture, University of Twente, 12 January 2006, p. 26, available at http://www.mb.utwente.nl/ces/research/other_publications_including_i/oratiewessel.pdf. The term, however, is quite common in biochemics, see for instance I. Olson, et al., 'Multilevel Regulation of Lysosomal Gene Expression in Lymphocytes', Biochemical and Biophysical Research Comunications, 1993, pp. 327-335; or V. Oke and R. Losick, 'Multilevel Regulation of the Sporulation Transcription Factor $\sigma \mathrm{K}$ in Bacillus subtilis', Journal of Bacteriology, 1993, pp. $7341-7347$. 
here, referring to the setting of rules, standards or principles that govern conduct by public and/or private actors. Whereas 'rules' are the most constraining and rigid, 'standards' leave a greater range of choice or discretion, while 'principles' are still more flexible, leaving scope to balance a number of (policy) considerations.

The purpose of the present contribution is to introduce and further analyse this relatively new phenomenon. We examine two questions: what are indications of interactions between normative processes at global, European and national level ${ }^{11}$; and what consequences do these interactions have for the research agenda related to the further development of the global and European legal order? In section 2 we first of all attempt to map and further define the phenomenon of multilevel regulation. This is followed in section 3 by an analysis of the responses from the legal community to this phenomenon. In section 4 we try to set out an agenda for further research, including legal and non-legal approaches.

\section{The Phenomenon of Multilevel Regulation}

\subsection{The Invasion of International Organisations}

International organisations and international regimes are increasingly engaged in normative processes which, de jure or de facto, impact on States and even on individuals and businesses. ${ }^{12}$ Since decisions of international organisations are increasingly coming to be considered a source of international law ${ }^{13}$, it is quite common to regard them in terms of international regulation or legislation. Whereas regulation, as stated above, is the more comprehensive term used in this contribution, 'legislation' has a more narrow connotation as 'legislative power' has been said to have three characteristics: (1) a written articulation of rules that (2) have legally binding effect as such and (3) have been promulgated by a process to which express authority has been delegated a priori to make binding rules without affirmative a posteriori assent to those rules by those bound. ${ }^{14}$ An even more

11 We largely leave out the more direct bi- or multilateral (transnational) relations between States. For an interesting theoretical analysis of the interdependence of regulatory policies of different countries see D. Lazer, 'Global and Domestic Governance: Modes of Interdependence in Regulatory Policymaking', ELJ, 2006, pp. 455-468.

12 See the contributions in Follesdal, Wessel and Wouters (eds.), op.cit.

13 See also I.F. Dekker and R.A. Wessel, 'Governance by International Organisations: Rethinking the Source and Normative Force of International Decisions', in: I.F. Dekker and W. Werner, (eds.), Governance and International Legal Theory, Leiden/ Boston: Martinus Nijhoff Publishers, 2004, pp. 215-236.

14 B. Oxman, 'The International Commons, the International Public Interest and New Modes of International Lawmaking', in J. Delbrück, (ed.), New Trends in International Lawmaking International Legislation in the Public Interest, Berlin: Duncker \& Humblot, 1996, pp. 21-60 at pp. 28-30. Cf. also T. Stein, 'Comment' in Delbrück, op.cit., pp. 212-213. C. Schreuder 
distinguishing element, perhaps, is that such rules imply future application to an indeterminate number of cases and situations. ${ }^{15}$

It is undisputed that international organisations may take binding decisions vis-à-vis their Member States and that they may even exercise sovereign powers, including executive, legislative and judicial powers. ${ }^{16}$ Thus, apart from the EC and the $\mathrm{UN}^{17}$, organisations with a competence to take legally binding decisions include the World Health Assembly of the WHO, the Council of the ICAO, the OAS, the WEU, NATO, OECD, UPU, WMO and IMF. ${ }^{18}$ As Alvarez notes, more and more technocratic international organisations "appear to be engaging in legislative or regulatory activity in ways and for reasons that might be more readily explained by students of bureaucracy than by scholars of the traditional forms for making customary law or engaging in treaty-making. They also often engage in law-making by subterfuge."19 Thus, Alvarez's survey includes standard setting by the IMO, the FAO, the ICAO, the ILO, the IAEA, UNEP, the World Bank, and the IMF. In addition, many international conventions - including UNCLOS (on the law of the sea) and a number of WTO agreements - incorporate generally accepted international "rules, standards, regulations, procedures and/or practices" (UNCLOS). ${ }^{20}$ Alvarez points to the fact that this may effectively transform a number of codes, guidelines and standards created by international organisations and bodies into binding norms. Indeed, while in most cases standard setting is accomplished through softer modes of regulation, this may leave the subjects of regulation "with as little effective choice as some Security Council enforcement actions". ${ }^{21}$ Nevertheless, most types of law making by international organisations are generally directed towards the organisation's own

('Comment' in ibid., pp. 213-215) points to the establishment by the Security Council of criminal tribunals as a sign of international legislation.

15 A.J.J. de Hoogh, 'Attribution or Delegation of (Legislative) Power by the Security Council?', in: M. Bothe and B. Kondoch, (eds.), The Yearbook of International Peace Operations, Vol. 7 2001, pp. 1-41, at p. 27. Cf. T. Stein, 'Comment' in Delbrück (see supra n. 13), pp. 212-213.

16 See quite extensively on this issue D. Sarooshi (see supra n. 3).

17 On decisions of the EU see e.g. A. von Bogdandy, F. Arndt and J. Bast, 'Legal Instruments in European Union Law and their Reform: A Systematic Approach on an Empirical Basis', Yearbook of European Law 2004, Oxford: Oxford University Press, 2005, pp. 91-136.

18 Cf. P.J. Sands and P. Klein, Bowett's Law of International Institutions, London: Sweet \& Maxwell, 2001; H.J. Schermers and N.M. Blokker, International Institutional Law: Unity within Diversity, Leiden: Martinus Nijhoff Publishers, 2003; J. Klabbers, An Introduction to International Institutional Law, Cambridge: Cambridge University Press, 2004; C.F. Amerasinghe, Principles of the Institutional Law of International Organizations, Cambridge: Cambridge University Press, 2005; and N.D. White, The Law of International Organisations, Manchester: Manchester University Press, 2005.

19 J.E. Alvarez (see supra 3), p. 217.

20 Ibid, Chapter 4.

21 Ibid., at p. 218. 
members, viz., States. ${ }^{22}$ But what if decisions by international organisations either de jure or de facto become part of the domestic legal order of the Member States and directly or indirectly affect citizens and/or businesses within those States?

While in most States the decisions of international organisations and bodies typically require implementation in the domestic legal order before they become valid legal norms, the density of the global governance web has caused an interplay between the normative processes at various levels. For EU Member States (and their citizens) this can imply that the substantive origin of EU decisions (which usually enjoy direct effect in, and supremacy over the domestic legal order) is to be found in another international body. ${ }^{23}$ In many areas, ranging from security to food safety, banking, health issues or the protection of the environment, national rules find their basis in international and/or European decisions. In those cases decisions may enter the domestic legal orders as part of European law. But international decisions may also have an independent impact on domestic legal orders. This is not to say that international decisions have a direct effect in the sense we are familiar with in EU law. From the point of view of international law, while "primacy is a matter of logic as international law can only assume its role of stabilizing a global legal order if it supersedes particular and local rules", at the same time it "allows for an undefined variety of combinations based either upon the doctrine of monism or the doctrine of dualism". ${ }^{24}$ However, the fact that many domestic legal orders do not allow their citizens to directly invoke international norms before national courts ${ }^{25}$ does not mean that these norms are devoid of impact. As the norms are usually based on international agreements and/or decisions of international organisations, States will simply have to follow the rules of the game in their international dealings. This implies that even domestically they may have to adjust to ensure that the rules are observed by all parts of the administration. The de facto impact of the - often quite

22 A number of international organisations also contain other international organisations as members: for instance, the WTO has the European Community as one of its founding members.

23 For a recent survey of the relations between the EU and other international organisations see: F. Hoffmeister, 'Outsider or Frontrunner? Recent Developments under International and European Law on the Status of the European Union in International Organizations and Treaty Bodies', CMLRev., Vol. 44 2007, pp. 41-68.

24 Th. Cottier, 'A Theory of Direct Effect in Global Law', in: A. von Bogdandy, et. al., (eds.), European Integration and International Co-ordination: Studies in Transnational Economic Law in honour of Claus Dieter Ehlermann, The Hague: Kluwer Law International, 2001, pp. 99-123 at p. 102 and p. 104.

25 For a recent survey of the different legal systems in Europe see: A. von Bogdandy, P.M. Huber and P. Cruz Villalón, (eds.), Ius Publicum Europaeum; Band I: Staatliches Verfassungsrecht im Europäischen Rechtsraum, Heidelberg: C.F. Müller Verlag, 2007. 
technical - norms and the need for consistent interpretation ${ }^{26}$ may thus set aside more sophisticated notions of the applicability of international norms in the domestic legal order.

The United Nations Security Council forms a good example of an international body that is increasingly active in the creation of 'international regulation' or 'international legislation', although its legal competence to engage in these activities has been questioned. ${ }^{27}$ Thus, in the area of anti-terrorism measures for example, Security Council Resolution 1390 (2002) was no longer directed at the Taliban regime but at individuals (Osama bin Laden, the Al-Qaeda network and the persons and entities associated with them). In that respect the resolution seems to herald a new development, as any connection with the territory of a State is omitted. Perhaps Resolution 1373 (2001) already pointed to something new when, in reaction to the terrorist attacks of 11 September, the Council determined "that such acts, like any act of international terrorism, constitute a threat to international peace and security", thus referring to terrorist acts in the abstract. The Council then imposed on all States duties to "prevent and suppress the financing of terrorist acts", inter alia by criminalising conduct aimed at financing or supporting terrorist acts.

Whereas its Charter presents the United Nations as an intergovernmental organisation dealing with the relations between its Member States (compare Arts. 1 and 2), taking decisions that entail obligations on those Member States (Art. 25), and extremely hesitant to interfere in the domestic jurisdiction of any State, the Security Council recently took a number of decisions that directly affect citizens within Member States. Key examples include the establishment of the Tribunals for the former Yugoslavia and for Rwanda, the cases in which the UN has taken over the

26 Ibid. on the impact of the doctrine of consistent interpretation in relation to the domestic effect of WTO law, pp. 109-110.

27 A.J.J. de Hoogh, 'Attribution or Delegation of (Legislative) Power by the Security Council?', in: M. Bothe and B. Kondoch, (eds.), International Peacekeeping. The Yearbook of International Peace Operations, Vol. 7 2001, pp. 1-41; and B. Eberling, 'The Ultra vires Character of Legislative Action by the Security Council', International Organizations Law Review, 2005, pp. 337-360. This development is often addressed to question the competence of the Security Council in this respect. See also recently: M. Akram and S.H. Shah, 'The Legislative Powers of the United Nations Security Council'; and A. Marschik, 'Legislative Powers of the Security Council', both in: R.S. MacDonald and D.M. Johnston, (eds.), Towards World Constitutionalism: Issues in the Legal Ordering of the World Community, Leiden: Martinus Nijhoff Publishers, 2005; S. Talmon, 'The Security Council as World Legislator', American Journal of International Law, 2005, pp. 175-193; and E. de Wet, 'The Security Council as a Law-Maker: The Adoption of (Quasi)-Legislative Decisions', in: R. Wolfrum and V. Röben, (eds.), Developments of International Law in Treaty Making, Berlin: Springer, 2005, pp. 184-225. The debate is somewhat older; see for instance E. Yemin, Legislative Powers in the United Nations and Specialised Agencies, Leiden: A.W. Sijthoff, 1996; and F.L. Kirgis, 'The Security Council's First Fifty Years', American Journal of International Law, 1995, p. 520. 
interim administration of a region or State (UNMIK in Kosovo and UNTAET in Timor Leste $^{28}$ and the replacement of traditional sanctions directed at States (e.g. Iraq) by 'smart sanctions' directed at certain individuals or groups. ${ }^{29}$ Thus the Security Council placed greater emphasis on its ability to take decisions with a great impact on intra-state issues rather than being involved merely in relations between States. Of course, even this development is not entirely new. By now we are used to the Council's occasional determination of (the effects of) domestic conflicts as threats to (international) peace and security. Moreover, the discussion on military intervention for humanitarian reasons highlighted the possible (and in the eyes of some even necessary) role of the Security Council in this area. ${ }^{30}$ In this sense it could be argued that the Security Council is no longer dealing with a particular situation between States or within a State, but with a more abstract situation that does not involve a particular dispute. Another example of an abstract danger could be Resolution 1422 (2002). By exempting certain "acts or omissions relating to a United Nations established or authorized operation" from the jurisdiction of the International Criminal Court, even though no ICC investigation was imminent, the Council in effect held the

28 For example, in relation to UNTAET, SC Resolution 1271 (1999) provides in para. 1 that UNTAET "[...] will be endowed with overall responsibility for the administration of east Timor and will be empowered to exercise all legislative and executive authority, including the administration of justice [...]." See also C. Stahn, "Governance beyond the State: Issues of Legitimacy in International Territorial Administration', International Organizations Law Review, 2005, pp. 9-56; B. Kondoch, 'The United Nations Administration of East Timor', Journal of Conflict and Security Law, Vol. 2 2001, pp. 245-265; and R. Wilde, 'Representing Territorial Administration: A Critique of Some Approaches', EJIL, 2004, pp. 71-96.

29 Smart sanctions are also referred to as 'targeted' or 'designer' sanctions. While the Afghanistan/Al-Qaeda sanctions renewed academic attention to this issue, comparable smart sanctions were for instance already established by Res. 1127 (1997) and 1173 and 1176 (1998) against UNITA (Angola); by Res. 1132 (1997) concerning Sierra Leone; Res. 1160 (1998) concerning Kosovo; Res. 1298 (2000) concerning Eritrea and Ethiopia; and by Res. 1343 (2001) concerning Liberia. More extensively see: I. Cameron, 'Targeted Sanctions, Legal Safeguards and the European Convention on Human Rights', Nordic Journal of International Law, 2003, pp. 159-214; R.A. Wessel, 'Debating the 'Smartness' of Anti-Terrorism Sanctions: The UN Security Council and the Individual Citizen', in: C. Fijnaut, J. Wouters and F. Naert (eds.), Legal Instruments in the Fight Against International Terrorism. A Transatlantic Dialogue, Leiden: Martinus Nijhoff Publishers, 2004, pp. 633-660. On the sanctions committees dealing with the cases see: G.L. Burci, 'Interpreting the Humanitarian Exceptions Through the Sanctions Committees', in: V. Gowlland-Debbas, (ed.), United Nations Sanctions and International Law, The Hague: Kluwer Law International, 2001, pp. 143-154, at pp. 144-145.

30 For a survey of Security Council activities in this area see: I. Österdahl, 'The Exception as the Rule: Lawmaking on Force and Human Rights by the UN Security Council', Journal of Conflict \& Security Law, 2005, pp. 1-20. Earlier: B. Graefrath, 'Leave to the Court What Belongs to the Court: The Libyan Case', European Journal of International Law, 1993, p. 184; M. Bedjaoui, The New World Order and the Security Council: Testing the Legality of its Acts, Dordrecht: Martinus Nijhoff Publishers, 1994; J.E. Alvarez, 'Judging the Security Council', American Journal of International Law, 1996, pp. 1-39; D.W. Bowett, 'The Court's Role in Relation to International Organisations', in: V. Lowe and M. Fitzmaurice, (eds.), Fifty Years of the International Court of Justice: Essays in Honour of Sir Robert Jennings, Cambridge: Cambridge University Press, 1996, pp. 181-192; and J. Dugard, 'Judicial Review of Sanctions', in: V. Gowlland-Debbas, United Nations Sanctions and International Law, The Hague: Kluwer Law International, 2001, pp. 83-91. 
abstract possibility of such an investigation to be a threat to peace. A particularly clear example is Resolution 1540 (2004), in which the Council again identified an abstract danger - the proliferation of weapons of mass destruction to non-State actors - as a threat to peace, and it again laid down a general obligation on all States that they shall refrain from assisting non-State actors in acquiring weapons of mass destruction, to criminalise the behaviour of non-State actors aimed at acquiring such weapons, etc. ${ }^{31}$ Earlier examples of resolutions attempting to 'regulate' a certain area without any relation to a specific conflict include the protection of civilians in armed conflicts and the spread of HIVIAIDS, as well as certain methods employed by terrorist groups. However, in this context the Council had not (yet) invoked its Chapter VII powers to lay down binding norms. ${ }^{32}$

The World Trade Organization is another body whose decisions have been labelled international regulation. ${ }^{33}$ While one may debate whether the decisions taken by the WTO's Dispute Settlement Body (DSB) are to been seen as proof of the organisation's 'legislative' or 'adjudicative' powers, the fact remains that they reach beyond the WTO Members involved in the dispute and may even have serious consequences for individuals (including enterprises in particular). ${ }^{34} \mathrm{~A}$ similar phenomenon may be discovered in another dimension of the WTO: intellectual property, regulated in the so-called TRIPs, ${ }^{35}$ which may affect the producers of HIVIAIDS medicines, in that an international decision ensures that their products may be sold under the market value in developing countries. Apart from the fact that the WTO has no facilities for individual access to a judicial review procedure such as those applicable within the EU, it may nevertheless find itself bound by Security Council resolutions, which may have a conclusive impact on the outcome of a WTO dispute settlement procedure.

31 B. Eberling, (see supra n. 26), pp. 337-360. On 'abstract' or 'thematic' decisions see also : C. Denis, Le Pouvoir normatif du Conseil de sécurité des Nations unies: Portée et limites, Brussels : Bruylant, 2004, paras. 118-130 en paras. 171-181; as well as J.E. Alvarez, (see supra n. 3), 2005, pp. 173-176.

32 B. Eberling, (see supra n. 30).

33 See in particular N. Lavranos: Decisions of International Organizations in the European and Domestic Legal Orders of Selected EU Member States, Groningen: Europa Law Publishing, 2004.

34 This forms one of the reasons for the debate on the constitutionalisation of trade law. See for instance D.Z. Cass, "The "Constitutionalization" of Trade Law: Judicial Norm-Generation as the Engine of Constitutional Development in International Trade', European Journal of International Law, 2001, pp. 39-75; as well as Cass, op.cit., 2005. On the impact of the WTO on the international legal order see the interesting book by J.H. Jackson, Sovereignty, the WTO and the Changing Fundamentals of International Law, Cambridge: Cambridge University Press, 2006.

35 On TRIPs see e.g. S.K. Sell, Private Power, Public Law: The Globalization of Intellectual Property Rights, Cambridge: Cambridge University Press, 2003. 
Other examples of international regulation can be found with the UN High Commissioner for Refugees (in relation to the fixing of standards regarding the establishment of a refugee status of the governance of refugee camps), the World Health Organization (in establishing global health risks), the so-called Financial Action Task Force of the OECD (in the area of money laundering), WIPO (in the area of intellectual property) and the World Bank (in setting criteria for obtaining financial support).

International norms do not always reach States' domestic legal order directly: they may have followed a route through other international bodies. In the European Union the relation between EU decisions and decisions taken by other international bodies is indeed quite obvious. ${ }^{36}$ Whereas this has been particularly apparent in the area covered by the internal market, the Union recently made clear that there is also an interplay between its decisions and United Nations anti-terrorism measures. In the Yusuf and Kadi cases, citizens of the Union did not succeed in having their names removed from UN and EU sanctions lists. ${ }^{37}$ The Member State in question (Sweden) was faced with the supremacy of EU law, whereas the European Court of First Instance held that the European Community is bound by UN law and the Court was in no position to judge the legality of UN Security Council Resolutions. At the same time the relationship between the European Community and the WTO may be regarded from a multilevel perspective. While the WTO is in no way comparable to the UN where questions of hierarchy and primacy are concerned, the ECJ has indicated the necessity that Community law be interpreted in conformity with WTO law. In that sense similar arguments to those used by the Court of First Instance in the Yusuf and Kadi cases could appear in cases where individuals claim to be a victim of a WTO (DSB) decision, in which case they would add to the already difficult position of individuals under WTO law. ${ }^{38}$

There thus seems to be a need to investigate the interplay between regulatory powers of international organisations. ${ }^{39}$ The close relationship between norms

See also Hoffmeister (see supra n. 22).

CFI Cases T-306/01, Ahmed Ali Yusuf and Al Barakaat International Foundation v. Council and Commission; and T-315/01, Yassin Abdullah Kadi v. Council and Commission, 21 September 2005. See also R.A. Wessel, 'The UN, the EU and Jus Cogens', International Organizations Law Review, 2006, No.1, pp. 1-6.

38 So far the direct effect of WTO law has not been accepted by the European Court of Justice. See for instance Case C-149/96, Portugal/Council. For examples in the area of international trade see: S. Shapiro, 'International Trade Agreements, Regulatory Protection and Public Accountability', Administrative Law Review, 2002, p. 435.

39 For a theoretical approach to regulatory interaction see also: V. Mayer-Schönberger and A. Somek, 'Introduction: Governing Regulatory Interaction: the Normative Question', ELJ, 2006, 
enacted by the World Health Organization, the World Trade Organization and the European Union, for instance, is quite obvious. ${ }^{40}$ The new International Health Regulations (IHR) as well as the WHO Framework Convention on Tobacco Control (FCTC) may be seen as examples. One could also point to the International Codex Alimentarius Commission, a subsidiary common body of FAO and WHO which develops international standards on food safety. It cannot be denied that - in particular through the WTO's Agreement on Sanitary and Phytosanitary Standards ${ }^{41}$ - these standards have an effect in other legal orders, including in those of the EU and its Member States. The fact that the European Community has been a Member of the Codex Alimentarius Commission since $2003^{42}$ reinforces the multilevel nature of this field of regulation. ${ }^{43}$ Similar examples may be found in the area of environmental protection, where international standards are set that are not only binding on States but also on the European Community and which - in any case through the latter - are also relevant to individuals. Heldeweg points to some examples in the area of tradable allowances. ${ }^{44}$ Regulation 2037/2000 on substances that deplete the ozone layer, ${ }^{45}$ implementing the Vienna Convention and Montreal Protocol $^{46}$, contains a system of trade through licences to import or export controlled substances from other countries (which may or may not be parties to the Montreal Protocol). More important, and certainly more innovative, may be the Directive establishing a scheme for greenhouse gas emission allowance trading within the Community. ${ }^{47}$ This scheme precedes the obligations under the first commitment period of the Kyoto Protocol (2008-2012) and aims to prepare the Community for

pp. 431-439 (Special issue of the ELJ Governing Regulatory Interaction: the Normative Question).

40 J. Wouters and B. De Meester, 'Safeguarding Coherence in Global Policy-Making on Trade and Health: The Triangle WHO - WTO - EU', International Organizations Law Review, 2005; and N. Lavranos, (see supra n. 32). On the influence of the EU on other international organisations see: L. Azoulai, 'The Acquis of the European Union and International Organisations', ELJ, 2005, pp. 196-331. The direct effect of WTO decisions in European Community law is still rejected by the European Court, as confirmed in such cases as C-377/02, Van Parys, 1 March 2005 and T19/01, Chiquita, 3 February 2005. On this topic see: P. Eeckhout, 'Does Europe's Constitution Stop at the Water's Edge? Law and Policy in the EU's External Relations', Walter van Gerven Lectures (5), Groningen: Europa Law Publishing, 2005, pp. 14-17.

$41 \quad$ Art. 3.4 and Annex A.3.a) SPS Agreement.

42 Council Decision 2003/822/EC of 17 November 2003 on the accession of the European Community to Codex Alimentarius Commission, O.J., 2003, L309/14. See F. Hoffmeister, (see supra n. 22), at p. 44.

43 Cf. also B.M.J. van der Meulen and A.A. Freriks, 'Millefeuille - The Emergence of a MultiLayered Controls System in the European Food Sector', Utrecht Law Review, 2006, pp. 156-176, available at $\mathrm{http}: / / \mathrm{www}$.utrechtlawreview.org

44 M.A. Heldeweg, 'Good Environmental Governance in the EU: Lessons from Work in Progress', in: D.M. Curtin and R.A. Wessel, Good Governance and the European Union: Some Reflections of Concepts, Institutions and Substance, Antwerpen: Intersentia, 2004, pp. 175-214.

45 OJ L 244/1, 2000.

46 OJ L 297/10, 1988 (Vienna Convention) and OJ L 299/21, 1988 (Montreal Protocol).

47 Directive 2003/87 (2003) OJ L 275. 
allowances trading. Finally, the effects on individuals are particularly evident in the framework of the so-called 'Aarhus regime'. The Aarhus Convention ${ }^{48}$ is an important multilateral environmental treaty to which the Community is a signatory and which is underpinned by three basic legal requirements in the area of openness and participation: a) access to environmental information; b) public participation; c) access to judicial review in environmental cases. Each of these requirements, also referred to as the 'Aarhus pillars', has given rise to legislation or proposals based thereon. In other cases, too, the EC is a party to international environmental treaties ${ }^{49}$, or is involved in their implementation on behalf of EU Member States. ${ }^{50}$

\subsection{The Expansion of Regulation: from Government to Governance}

In their interdisciplinary survey of research on regulation, Baldwin, Scott and Hood developed three definitions of regulation. ${ }^{51}$ In the first, most stringent definition, regulation refers to the promulgation of an authoritative set of standards and rules accompanied by some mechanism for promoting and monitoring compliance with these rules and standards. A second, broader definition refers to all the efforts of State agencies to steer individual and organisational behaviour. This approach takes account of other policy instruments which a State may use to influence behaviour, such as taxation, disclosure requirements, procurement policies, etc. A third approach to regulation considers all mechanisms of social control, including nonState processes. In recent times, in addition to the standard setting practice of international organisations referred to above, it is especially this third type, with new forms of social or 'privatised' regulation that is on the rise and is even proliferating. This evolution is taking place in a context of trends such as the weakening of national governments, the rise and professionalisation of multinational corporations and supply chains, and the proliferation, diversification and internationalisation of

\footnotetext{
48 Convention on Access to Information, Public Participation in Decision Making and Access to Justice in Environmental Matters, signed by the EC on the $25^{\text {th }}$ of June 1998; COM(1998) 344 final.

49 R.A.J. van Gestel and J.M. Verschuuren, 'Internationaal en Europees milieurecht in Nederland? Gewoon toepassen!' [International and European Environmental Law in the Netherlands? Just apply it!], SEW, 2005, pp. 244-251. The authors refer to the Treaty of Basel, the UN/ECE Treaty of Helsinki, the Kyoto Protocol of the UN Climate Treaty, the Treaty of Bern, and the 2001 UNEP Treaty on POP's. See Basel: http:/www.basel.int/text/text.html; Helsinki: http://www.unece.org/env/water/welcome.html; Kyoto: http:/unfccc.int/2860.php; Bern: http://conventions.coe.int/treaty/en/Treaties/Html/104.htm; Aarhus: http://www.unece.org/env/pp/; POP: http://www.pops.int/; CITES: http://www.cites.org/

50 See for instance the Convention on International Trade in Endangered Species of Wild Fauna and Flora (CITES).

51 R. Baldwin, C. Scott and C. Hood, 'Introduction', pp. 1-55, in: R. Baldwin, et. al., (eds.) A Reader on Regulation, Oxford: Oxford University Press, 1998, pp. 3-4.
} 
new social movements and their strategies. ${ }^{52}$ This shift is often referred to as a shift from government to governance in regard to policy making.

Traditionally, social problems or public policy issues were governed by States via a regulatory framework consisting of bureaucracies (departments, ministries) and legislation. This top-down, command-and-control approach aimed at setting and implementing standards which are/were applicable to all parties involved in the same way. From the 1980s on, though, the deficiencies of this approach started to emerge in both old and new policy fields, ${ }^{53}$ leading to the development of new policy instruments and arrangements. A major policy shift constitutes a move away from the State as the sole actor in policy making. The State traditionally acted in a top-down, command-and-control fashion. However, apart from an increasing role of international organisations and bodies (supra, 2.1.), new modes of policy making are characterised by a greater role for private actors, either via intensive negotiation, consultation, interaction, and even self-regulation, or via increasing economic and market-oriented strategies and instruments. ${ }^{54}$ This broadening of the 'spectre of intervention' implies a fundamental redefinition of the role of the State ${ }^{55}$ : the State should no longer row but steer ${ }^{56}$, focus more on means

52 T. Bartley, 'Certifying Forests and Factories: States, Social Movements, and the Rise of Private Regulation in the Apparel and Forest Products Fields', Politics and Society, Vol. 31(3) 2003, pp. 433-464; B. Cashore, "Legitimacy and the Privatization of Environmental Governance: How Non-state Market-driven (NSMD) Governance Systems Gain Rule-making Authority", in: Governance - An International Journal of Policy and Administration, Vol. 15(4) 2003, pp. 503529; D. O'Rourke, 'Outsourcing Regulation: Analyzing Nongovernmental Systems of Labor Standards and Monitoring', Policy Studies Journal, Vol. 31(1) 2003, pp. 1-29; A. Fung, 'Making Social Markets: Dispersed Governance and Corporate Accountability' in: John D. Donahue and Joseph S. Nye, (eds.), Market Based Governance, Washington, D.C.: Brookings Institution Press, 2003; G. Gereffi, et al., The NGO-industrial complex, Foreign Policy, Vol. 125 2001, pp. 56-65; C. Sabel, 'Learning by Monitoring: The Institutions of Economic Development', pp. 137-165, in: N. Smelser and R. Swedberg, (eds.), Handbook of Economic Sociology, Princeton: Princeton University Press, 1994; C. Sabel, Ratcheting Labor Standards. Regulation for Continuous Improvement in the Global Workplace, Washington: World Bank, 2000.

53 See inter alia M. Jänicke, State Failure - the Impotence of Politics in Industrial Society, Cambridge: Polity Press, 1990. C. Crouch and D. Marquand, (eds.), Ethics and Markets. Cooperation and Competition within Capitalist Economies, Oxford: Blackwell Publishers, 1993; J. van Tatenhove, et al., (eds.), Political Modernisation and the Environment. The Renewal of Environmental Policy Arrangements, Dordrecht: Kluwer Academic Publishers, 2000; A. Mol, 'Ecological Modernisation and Institutional Reflexivity: Environmental Reform in the Late Modern Age', Environmental Politics, Vol. 5(2) 1996, pp. 302-23; M. Hajer, The Politics of Environmental Discourse. Ecological Modernisation and the Policy Process, Oxford: Clarendon Press, 1995.

54 D. Liefferink, M.S. Anderesen and M. Eneveldsen, 'Interpreting Joint Environmental PolicyMaking: Between Deregulation and Political Modernization', in: A. Mol, et al., (eds.), The Voluntary Approach to Environmental Policy. Joint Environmental Policy-Making in Europe, Oxford: Oxford University Press, 2000, pp. 10-31, at p. 14.

55 D. Liefferink, et al., 'Interpreting Joint Environmental Policy-Making: Between Deregulation and Political Modernization', pp. 10-31, in: A. Mol, et al., (eds.), (see supra n. 53); M. Jänicke, State Failure - the Impotence of Politics in Industrial Society, Cambridge: Polity Press, 1990, p. 166.

56 D. Osborne and T. Gaebler, Reinventing Government, New York: Basic Books, 1992. 
than on ends ${ }^{57}$ and concentrate more on organisation and direction rather than provision. ${ }^{58}$ The new policy catchwords are bottom-up policy processes, empowerment, the importance of learning processes, (open methods of) coordination, co-operation, consensus, flexibility, tailor-made solutions, self-regulation, public-private partnerships, participation and benchmarking. Tatenhove, adopting a European perspective, identified the following major policy changes: "'(a) the traditional divides between state, market and civil society are disappearing, while (b) the interrelations between these spheres increasingly exceed the nation state, (c) resulting in new coalitions between state agencies, market agents and civic parties both on local and global levels". ${ }^{59}$ The overall result is a policy style characterized by plurality in terms of policy instruments, coalitions between parties, the allocation and distribution of power and new forms of co-operation. In the United States, too, legal scholars and political scientists describe the emergence of a new democratic model: "The emergent model, which we call democratic experimentalism, combines the virtues of localism, decentralization, and direct citizen participation with the discipline of national coordination, transparency, and public accountability." some American scholars these new models try to combine the virtues of localism, decentralisation, and direct participation with the discipline of international or national co-ordination and public accountability. ${ }^{61}$ "In contrast to conventional hierarchical regulation in which subordinate private actors answer to the authoritative command of a central regulator, the practical core of the new model is centrally monitored local experimentation." ${ }^{2}$

57 D. Miliband, 'The New Politics of Economics', in: C. Crouch and D. Marquand, (eds.), Ethics and Markets. Co-operation and Competition within Capitalist Economies, Oxford: Blackwell Publishers, 1993, pp. 21-30.

58 G. Mulgan, 'Reticulated Organisations: The Birth and Death of the Mixed Economy', in: C. Crouch, et al., (eds.), Ethics and Markets. Co-operation and Competition within Capitalist Economies, Oxford: Blackwell Publishers, 1993, pp. 31-47; G. Mulgan, Politics in an Antipolitical Age; Cambridge: Polity Press, 1994.

59 J. van Tatenhove, B. Arts and P. Leroy, 'Political Modernisation', in: J. van Tatenhove, et al., (eds.), Political Modernisation and the Environment. The Renewal of Environmental Policy Arrangements, Dordrecht: Kluwer Academic Publishers, 2000, pp. 35-51, at p. 48.

60 B. Karkkainen, A. Fung and C. F. Sabel, 'After Backyard Environmentalism. Towards a Performance-Based Regime of Environmental Regulation', American Behavioral Scientist, Vol. 44(4) 2000, pp. 692-711, at p. 692.

61 D. Esty and D. Geradin, (eds.), Regulatory Competition and Economic Integration: Comparative Perspectives. 2001, Oxford U.K.: Oxford University Press; B. Karkkainen, A. Fung and C. F. Sabel, (see supra n. 59), pp. 692-711; C. Sabel, 'Learning by Monitoring: The Institutions of Economic Development', in: N. Smelser and R. Swedberg, (eds.), Handbook of Economic Sociology, 1994, Princeton: Princeton University Press, pp. 137-165; C.F. Sabel, A. Fung and D. O'Rourke, Ratcheting Labor Standards. Regulation for Continuous Improvement in the Global Workplace, Washington: World Bank, 2000 ; M. Dorf and C.F. Sabel, 'A Constitution of Democratic Experimentalism', Columbia Law Review, March 1998, pp. 267-473.

62 B. Karkkainen, A. Fung and C.F. Sabel, (see supra n. 59), p. 691. 
These new forms of governance are considered superior to existing policy making strategies because they are assumed to improve the substantive quality of decisions and policy making by incorporating new and more information obtained from the different participants; increase learning processes among the participants (educating the actors involved) and in this way generate new knowledge; with better incorporation of public values into decisions; they are supposed to resolve, contain or reduce conflict among competing interests and the actors involved, integrate local knowledge and context in decision making, hence tailoring it to local circumstances; they achieve cost-effectiveness; and they increase compliance via greater commitment to and support for the implementation of decisions. ${ }^{63}$ Existing policy practices are criticised for being overly rigid (rules that hold across a nation and nations) and for their limitations in being able to incorporate local and specific information in the design of solutions.

As a result of this policy shift one can observe, both nationally and internationally, the emergence of new co-operative policy initiatives and new forms of governance, such as public and stakeholder participation in decision making ${ }^{64}$, voluntary agreements and covenants, self-regulation by companies via the introduction of management systems and codes of conduct $^{65}$, stakeholder partnerships for the

63 T. Beierle and J. Cayford, Democracy in Practic, Washington: Resources for the Future, 2002; T. Beierle, Public Participation in Environmental Decisions: An Evaluation Framework Using Social Goals. Discussion paper 99-06, Resources for the Future, 1998; C. Sabel, 'Learning by Monitoring: The Institutions of Economic Development', in: N. Smelser and R. Swedberg, (eds.) (see supra n. 60), pp. 137-165; M. Dorf and C.F. Sabel (see supra n. 60), pp. 267-473; B. Karkkainen, A. Fung and C. F. Sabel, (see supra n. 59), pp. 692-711; S. Helper, J.P. MacDuffie and C.F. Sabel, 'Pragmatic Collaborations: Advancing Knowledge While Controlling Opportunism', Industrial and Corporate Change, Vol. 9(3) 2000, pp. 443-488; C. Coglianese and J. Nash, 'Environmental Management Systems and the New Policy Agenda', in: C. Coglianese, and J. Nash, (eds.), Regulating from the Inside: Can Environmental Management Systems achieve Policy Goals, Washington: Resources for the Future, 2001; C. Coglianese, Is Consensus an Appropriate Basis for Regulatory Policy? Paper Harvard University. John F. Kennedy School of Government, 2002; G. Cowie and L. O'Toole, 'Linking Stakeholder Participation and Environmental Decision-Making', pp. 61-75, in: F.H. Coenen, et al., (eds.), Participation and the Quality of Environmental Decision-Making, Dordrecht: Kluwer Academic Publishers, 1998; B. de Sousa Santos, 'Participatory Budgeting in Porto Alegre: Toward a Redistributive Democracy', Politics and Society, Vol. 26 1998, pp. 461-510; G. Baiocchi, 'Participation, Activism and Politics. The Porto Alegre Experiment', in: A. Fung and E.O. Wright, (eds.), Deepening Democracy. Institutional Innovations in Empowered Participatory Governance, London: Verso, 2003, pp. 45-76.

64 T. Beierle and J. Cayford, Democracy in Practice, Washington: Resources for the Future, 2002; T. Beierle (see supra n. 62); G. Cowie and L. O'Toole, 'Linking Stakeholder Participation and Environmental Decision-making', in: F.H. Coenen, et al., (eds.), Participation and the Quality of Environmental Decision-Making, Dordrecht: Kluwer Academic Publishers, 1998, pp. 61-75.

65 C. Coglianese and J. Nash, (eds.), Regulating from the Inside: Can Environmental Management Systems Achieve Policy Goals, Washington: Resources for the Future, 2001; K. Kollman and A. Prakash, 'EMS-based Environmental Regimes as Club Goods: Examing Variations in Firm-level Adoption of ISO 14001 and EMAS in UK, US and Germany', Policy Sciences, Vol. 35 2002, pp. 43-67; I. Mamic, Implementing Codes of Conduct. How Businesses manage social performance 
management of ecosystems or the monitoring of human rights issues and labour conditions on a global scale $^{66}$, collaborative pragmatism ${ }^{67}$, the development of corporate social responsibility models and the rise and proliferation of accreditation and certification bodies such as the Forest Stewardship Council, Fair Labour Association or Marine Stewardship Council. ${ }^{68}$

\subsection{Governance and Regulation as a Multi-actor Game}

What has been set out above already indicates that governance, and by the same token regulation, has become a multi-actor game: apart from intergovernmental organisations, non-governmental and transnational actors are playing an increasing role in global governance. ${ }^{69}$ In some issue areas there is intense co-operation between State and non-State actors. Apart from the obvious example of the International Labour Organization, one could point to the Codex Alimentarius Commission (supra, 2.1.) or to ICANN ${ }^{70}$, which governs the internet. In some areas States have even ceased to play a role and transnational actors have taken over. A prime example is the International Standardization Organization (ISO), which by now has produced some 13,000 rules on the standardisation of products and processes. ${ }^{71}$ These rules are often adopted by other international organisations,

in global supply chains, Geneva: ILO, 1994; World Bank, Company Codes of Conduct and International Standards: An Analytical Comparison, Washington: Worldbank, 2003.

66 W. Leach, N.W. Pelkey and P. Sabatier, 'Stakeholder Partnerships as Collaborative Policymaking: Evaluation Criteria Applied to Watershed Management in California and Washington', Journal of Policy Analysis and Management, Vol. 21(4) 2002, pp. 645-670.

67 B. Karkkainen, A. Fung and C. F. Sabel, '(see supra n. 59), pp. 692-711; B. Karkkainen, 'Towards Ecologically Sustainable Democracy', in: A. Fung and E.O. Wright, (eds.), Deepening Democracy. Institutional Innovations in Empowered Participatory Governance, London: Verso, 2003, pp. 208-224.

68 T. Bartley, 'Certifying Forests and Factories: States, Social Movements, and the Rise of Private Regulation in the Apparel and Forest Products Fields', Politics and Society, Vol. 31(3) 2003, pp. 433-464; B. Cashore, 'Legitimacy and the Privatization of Environmental Governance: How Non-state Market-driven (NSMD) Governance Systems Gain Rule-making Authority, Governance - An International Journal of Policy and Administration, Vol. 15(4) 2003, pp. 503529; B. Cashore, G. Auld and D. Newsom, Governing through Markets: Forest Certification and the Emergence of Non-State Authority, New Haven: Yale University Press, 2004; D. O’Rourke, 'Outsourcing Regulation: Analyzing Nongovernmental Systems of Labor Standards and Monitoring', Policy Studies Journal, Vol. 31(1) 2003, pp. 1-29.

69 Anne-Marie Slaughter regards these networks as a better way of world governance than the traditional statecentric approach. See her A New World Order, 2004, Boston MA: Princeton University Press. Another relevant dimension is not addressed in this contribution. Apart from transnational networks, the international legal order is also challenged by 'hegemonic international law' (HIL). On the influence of hegemons see also J.E. Alvarez, (see supra n. 3), pp. 199-217 as well as G. Simpson, Great Powers and Outlaw States: Unequal Sovereigns in the International Legal Order, Cambridge: Cambridge University Press, 2004.

70 Internet Corporation for Assigned Names and Numbers.

71 R.B. Hall and Th.J. Biersteker, (eds), The Emergence of Private Authority in Global Governance, Cambridge: Cambridge University Press, 2002. 
such as the WTO, which allows them to indirectly affect national legal orders. ${ }^{72} \mathrm{~A}$ similar situation arises in relation to the norms set by the World Anti-Doping Agency. It is clear that individuals or companies may be confronted by rules that were adopted without any direct influence by the national legislator or that simply have to be adopted at the national level in order to be able to participate in international cooperation. Something like global law without the State ${ }^{73}$ does exist and in some areas States do not play any role in global regulation. What one witnesses is a transnational co-operation that has already led to a complete set of rules on the use of the internet: the lex digitalis, comparable to the lex mercatoria related to transnational trade. ${ }^{74}$ Other examples include the Basel Committee, in which the central bank directors of a limited number of countries harmonise their policies in such a way as to result in a de facto regulation of the capital market ${ }^{75}$, and the International Organization of Securities Commissions (IOSCO), which deals with the transnationalisation of securities markets and attempts to provide a regulatory framework for them. ${ }^{76}$ National agencies thus participate in global (or regional) regulatory networks as independent, autonomous actors and are, in turn, often required to implement international regulations or agreements adopted in the context of these networks at the national level. ${ }^{77}$ As early as a decade ago, Slaughter termed this phenomenon the "nationalization of international law". ${ }^{78}$ According to Jayasuriya these new regulatory forms have three main features: 1 . they are governed by networks of State agencies acting not on behalf of the State but as independent actors; 2. they lay down standards and general regulatory principles rather than strict rules; and 3. they frequently contribute to the emergence of a system of decentralised enforcement or the regulation of self-regulation. ${ }^{79}$

72 S. Shapiro, 'International Trade Agreements, Regulatory Protection and Public Accountability', Administrative Law Review, 2002, p. 435.

73 For the contribution to the fragmentation of law see Fischer-Lescano and Teubner, (see infra n. 104), p. 1009.

74 On the lex digitalis see for instance H.H. Perritt Jr., 'Dispute Resolution in Cyberspace: Demand for New Forms of ADR', Ohio State Journal on Dispute Resolution, 2000, pp. 675-692. On the lex mercatoria see for instance L.M. Friedman, 'Erewhon: The Coming Global Legal Order', Stanford Journal of International Law, 2001, pp. 347-359.

75 D. Zaring, 'International Law by Other Means: The Twilight Existence of International Financial Regulatory Organizations', Texas International Law Review, 1998, p. 281; M.S. Barr and G.P. Miller, 'Global Administrative Law: The View from Basel', EJIL, 2006, pp. 15-46.

76 Ibid.; and Jayasuriya (see supra n. 3), p. 449.

77 Jayasuriya (see supra n. 3), p. 440. See also S. Picciotto, 'The Regulatory Criss-Cross: Interaction Between Jurisdictions and the Construction of Global Regulatory Networks', in: W. Bratton, et al., (eds.), International Regulatory Competition and Coordination: Perspectives on Economic Regulation in Europe and the United States, Oxford: Clarendon Press, 1996, pp. 89123.

78 A.-M. Slaughter, 'The Real New World Order', Foreign Affairs, 1997, pp. 183 et seq., at p. 192.

79 Jayasuriya (see supra n. 3), p. 453. On the regulation of self-regulation in particular see G. Teubner, 'Substantive and Reflexive Elements in Modern Law', Law \& Society, 1983, pp. 239281. Elements of this development are also addressed by A.-M. Slaughter, (see supra n. 68). 
Apart from non-governmental bodies and national agencies making their own international deals, a relatively new development is the proliferation of international bodies that are not based on an international agreement but on a decision by an international organisation. According to some observers these new international entities even outnumber the conventional organisations. ${ }^{80}$ International regulatory cooperation is often conducted between these non-conventional international bodies. ${ }^{81}$ The tendency towards functional specialisation because of the technical expertise required in many areas may be a reason for the proliferation of such bodies and for their interaction with other international organisations and agencies, which sometimes leads to the creation of common bodies, such as the Global Environmental Facility (GEF, created by the World Bank and joined by EBDP and UNEP) and UNAIDS, the Joint United Nations Programme on HIVIAIDS (instituted by UNICEF, UNDP, UNFPA, UNESCO, WHO and the World Bank). ${ }^{82}$ Whereas traditional international organisations are established by an agreement between States, in which their control over the organisation and the division of powers is laid down ${ }^{83}$, the link between newly created international bodies and the States that established the parent organisation is less clear. In a recent study Martini points to fundamental sectors, such as environmental protection and public health ${ }^{84}$, where the Global Environmental Facility (GEF, created by the World Bank and joined by EBDP and UNEP) and the Joint United Nations Programme on HIVIAIDS (UNAIDS, instituted by UNICEF, UNDP, UNFPA, UNESCO, WHO and the World Bank) "demonstrate how the entity's will does not simply express the sum of the Member States' positions, but reformulates them at a higher level of complexity, assigning decision-making power to different subjects, especially to the international

80 See the early study by C. Shanks, H.K. Jacobson and J.H. Kaplan, 'Inertia and Change in the Constellation of International Governmental Organizations, 1981-1992', International Organization, 1996, pp. 593 et seq..

81 Cf. also C. Tietje, 'Global Governance and Inter-Agency Cooperation in International Economic Law', Journal of World Trade, 2002, p. 501.

82 On this phenomenon of what she terms the 'new international organization', see in particular the interesting contribution by C. Martini, 'States' Control over New International Organization', Global Jurist Advances, 2006, pp. 1-25.

83 On the different dimensions of the relationship between states and international organizations cf. D. Sarooshi, (see supra n. 3).

84 See also M. Forrest, 'Using the Power of the World Health Organization: The International Health Regulations and the Future of International Health Law', Colum. J.L. \& Soc. Probs., 2000 (putting the legislative powers of the WHO into perspective); and D.P. Fodler, 'Global Challenges to Public Health: SARS: The Political Pathology of the First Post-Westphalian Pathogen', J. Med. \& Ethics, 2004 (on the possible implications of WHO regulations for national sovereignty). For the environmental sector see R.R. Churchill and G. Ulfstein, 'Autonomous Institutional Arrangements in Multilateral Environmental Agreements: A Little-Noticed Phenomenon in International Law', AJIL, Vol. 4 2000, pp. 623-659. 
institutions that promoted the establishment of the new organization." ${ }^{85}$ Martini's study reveals that the loss of States' influence - and hence the autonomous position of international agencies - is reflected in at least three phenomena ${ }^{86}$ : (i) the fact that the new entities emerge from the regular decisions of other organisations, rather than through the treaty-making process, compromises States' ability to influence not only their creation but also their further development; (ii) States may lose some powers to the parent organisations, such as the power to appoint the new entity's executive heads; moreover, they might have to share the power to define and manage the organisation's activities; and (iii) in the non-State-created organisations the international secretariat plays a greater role. This is not to say that all these international bodies can readily be compared with each another: "In fact, these institutions are established in different ways, have different institutional structures and relationships with their parent organizations, and different areas of activity and functions". ${ }^{87}$ However, the need for collaboration between international agencies and the subsequent creation of common organisations has resulted in a global regulatory sphere in which States are more often confronted with a decrease in the influence they have on global normative processes.

\section{The Response from the Legal Community}

Legal studies have only recently started to recognise the phenomena described above. After all, the international legal system is formed on the basis of legally autonomous national legal orders, which are in principle exclusively competent to create, implement and enforce legal norms. Nevertheless, an increasing number of studies depart from the notion that the national legal order is part of a multilevel international legal order and that the creation, application and interpretation of national as well as international norms should take account of the multilevel structure of the system. With the development of the international legal order we have grown accustomed to legal norms being developed outside the national legal orders. The proliferation of rule makers at the international level poses new challenges to the coherence of this order. While treaties and custom remain the primary sources of international law, we have seen above that decisions of international organisations are playing an ever larger part in the development of international law. As national governments have become increasingly dependent on international institutions, a

Martini, op.cit., p. 25.

Ibid., p. 24.

Ibid., p. 2. 
large part of national policy is influenced by and depends on international decisions. Although States do not cease to exist by becoming a member of an international (integration) organisation, it becomes very difficult to regard their national legal order as existing in complete isolation from the legal system of the organisation. The 'constitutional setting' in which they operate may depend in large part on general international law, and at least clearly includes the arrangements to which they agreed in the context of the international organisation in question. Conversely, the international organisation has to deal with the Janus-faced identity of Member States: on the one hand Member States are an integral part of the international organisation they set up among themselves; on the other hand the States are the counterparts of the same international organisation, in the sense that both occupy independent positions within the international legal order and even have obligations towards each other.

The legal community has developed a variety of approaches to deal with this complexity: (i) constitutionalism, (ii) global administrative law, (iii) fragmentation of international law. ${ }^{88}$

\subsection{Constitutionalism}

The combination of the phenomenon of multilevel governance and the related declining ability of States to achieve the realisation of human rights, fundamental freedoms and democratic procedures, has led a number of legal scholars to view constitutionalism in multilevel terms. On the one hand it is assumed that globalisation may strengthen the protection of fundamental values at the national level, e.g. through a constitutionalisation of human rights (as experienced for instance in Europe with the European Convention on Human Rights and Fundamental Freedoms and the extensive case law of the European Court of Human Rights). On the other hand, global processes may undermine these values, as a result, for instance of the limited (democratic or otherwise) legitimacy of international decisions ${ }^{89}$ and deficits in accountability, the rule of law (e.g. the lack of a possibility

88 Interestingly, almost all the legal scholars in question have a background in international law. Scholars active in the areas of constitutional law and legal theory seem to be more prone to adopt a comparative approach, continuing to see the State as the central reality and not really focussing on normative processes in the international legal order. See e.g. W. Twining, Globalization and Legal Theory, 2000, Cambridge U.K.: Cambridge University Press. An author who does pay attention to developments at the global level is B. Tamanaha, On the Rule of Law: History, Politics, Theory, Cambridge: Cambridge University Press, 2004.

89 See also M. Kumm, 'The Legitimacy of International Law: A Constitutionalist Framework of Analysis', EJIL, Vol. 5 2004, pp. 907-931. On a number of these issues see also J.-M. Coicaud and V. Heiskanen, (eds.), The Legitimacy of 
for review by an independent judiciary ${ }^{90}$ ) and transparency. In the words of Petersmann, "the inevitable 'democratic deficit' of worldwide organisations for the collective supply of 'global public goods' must be compensated for by subjecting their multilevel governance to multilevel constitutional restraints at both international and domestic levels." ${ }^{91}$ While the trend towards approaching international organisations from a constitutional perspective started in relation to the European Union ${ }^{92}$, other international organisations have become subject to academic constitutional scrutiny as well. ${ }^{93}$ In fact, as one observer holds: "If anyone were to propose a pairing of phrases to characterize current developments in international law, the smart money would surely be on constitutionalisation and fragmentation. [M]any international

International Organizations, Tokyo: United Nations University Press, 2001. Already a classic is E. Stein, 'International Integration and Democracy: No Love at First Sight', AJIL, 2001, pp. 489-534. See also S. Wheatley, 'Democratic Governance Beyond the State: The Legitimacy of Non-State Actors as Standard Setters', in: The Role of Non-State Actors in Standard Setting, Basel Institute on Governance (forthcoming, 2008).

90 See, e.g., on the problems related to judicial review of UN Security Council decisions, E. de Wet, The Chapter VII Powers of the United Nations Security Council, Oxford: Hart Publishing, 2005; $\mathrm{K}$. Manusama, The United Nations in the Post-Cold War Era: Applying the Principle of Legality, Leiden: Nijhoff, 2006.

91 E.-U. Petersmann, 'Multilevel Trade Governance in the WTO Requires Multilevel Constitutionalism', in: C. Joerges and E.-U. Petersmann, (eds.), Constitutionalism, Multilevel Trade Governance and Social Regulation, Oxford: Hart Publishing, 2006; J.P. Trachtman, 'The World Trading System, the International Legal System and Multilevel Choice', ELJ, 2006, p. 469; and R. Uerpmann-Wittzack, 'The Constitutional Role of Multilateral Treaty Systems', in: A. von Bogdandy and J. Bast, Principles of European Constitutional Law, Oxford: Hart Publishing, 2006, pp. 145-181. See also I. Pernice, 'Multilevel Constitutionalism in the European Union', European Law Review, 2002, pp. 511-529; and R.A. Wessel, 'The Multilevel Constitution of European Foreign Relations', in: N. Tsagourias, (ed.), Transnational Constitutionalism: International and European Perspectives, Cambridge: University Press, 2007.

92 See for instance G. Frankenberg, 'The Return of the Contract: Problems and Pitfalls of European Constitutionalism', ELJ Vol. 3 2000, pp. 257-76; J. Schwartze, (ed.), The Birth of a European Constitutional Order: The Interaction of National and European Constitutional Law, London: Sweet \& Maxwell, 2001; A. von Bogdandy and J. Bast, (eds.), Principles of European Constitutional Law, Oxford: Hart Publishing, 2006; J.H.H. Weiler, The Constitution of Europe, Cambridge: Cambridge University Press, 1999.

93 See for instance E.-U. Petersmann, 'Constitutionalism and International Organisations', Northwestern Journal of International Law \& Business, 1996, p. 398; as well as his 'Human Rights, Constitutionalism and the World Trade Organization: Challenges for World Trade Organization Jurisprudence and Civil Society', Leiden Journal of International Law, 2006, pp. 633-667; D.Z. Cass, The Constitutionalization of the WTO, Oxford: Oxford University Press, 2005 (claiming, however, that the WTO is not and should not be constitutionalised); B. Fassbender, 'The United Nations Charter as Constitution of the International Community', Col. J. Tran'l L., Vol. 36 1998, pp. 529 et seq.; and his 'The Meaning of International Constitutional Law', in: R. St. MacDonald and D.M. Johnston, (see supra n. 26), p. 837. 
lawyers propose that treaty regimes be constitutionalized, and voice such proposals in particular in the context of international organizations". ${ }^{4}$

Important parts of the changing nature of the international legal order are studied in what is frequently referred to as 'international constitutional law'. ${ }^{95}$ One of the questions in international constitutional law is whether a so-called domestic analogy ${ }^{96}$ is useful and to what extent one has to take account of the fact that global governance acknowledges no single government ${ }^{97}$ but rather numerous different actors at various levels, all in their own manner influencing policy making and, for our purpose, rule making through complex, often interrelated processes.

\subsection{Global Administrative Law}

Another manner in which global governance and regulation is being tackled by legal scholarship is the so-called 'global administrative law' approach. The term was introduced by Kingsbury, Krisch and Stewart when they launched a project under this title at New York University. They define global administrative law as "comprising the structures, procedures and normative standards for regulatory decision-making, including transparency, participation, and review, and the rule-governed mechanisms for implementing these standards, that are applicable to formal intergovernmental regulatory bodies; to informal intergovernmental regulatory networks; to regulatory decisions of national governments where these are part of or constrained by an intergovernmental regime; and to hybrid public-private or private transnational

94 J. Klabbers, 'Constitutionalism Lite', International Organizations Law Review, 2004, pp. 31-58, who also points to some of the inherent paradoxes of constitutionalism.

95 E. de Wet, 'The International Constitutional Order', ICLQ, 2006, pp. 51-76; R. St. MacDonald and D.M. Johnston, (see supra n. 26); N. Tsagourias, (see supra n. 90); B. Ackerman, 'The Rise of World Constitutionalism', Virginia Law Review, 1997, p. 771; S. Kadelbach and Th. Kleinlein, 'Überstaatliches Verfassungsrecht: Zur Konstitutionalisierung im Völkerrecht' [Supranational Constitutional Law: On the Constitutionalisation of International Law], Archiv des Völkerrechts, 2006, pp. 235-266. For an earlier reference see A. Verdross, Die Verfassung der Völkerrechtsgemeinschaft, Vienna: Springer Verlag, 1926. For a (US) critique: E.A. Young, 'The Trouble with Global Constitutionalism', Texas International Law Journal, 2003, p. 527. As for instance propagated by R.B. Stewart, 'U.S. Administrative Law: A Model for Global Administrative Law', IILJ Working Paper, Vol. 7 2005, available at http://www.iilj.org. In this contribution we leave aside the consequences of globalization for national administrative law as a result of the changing role of the State due to both the increasing interplay between national and international law and between the public and private sector. On this topic see for instance: A.C. Aman, Administrative Law in a Global Context, Ithaca: Cornell University Press, 1992; A.C. Aman, "Administrative Law for a New Century", in: M. Taggert, (ed.), TheProvince of Administrative Law, Oxford: Hart Publishing, 1997; and J. Delbrück, Globalization of Law, Politics and Markets - Implications for Domestic Law - A European Perspective", Ind. J. Global Legal Studies, 1993, p. 9. For the consequences of the constitutional order of (in this case) the United States: M. Tushnet, TheNew Constitutional Order, 2003, Princeton: Princeton University Press, Ch. 5: Globalization and the New Constitutional Order.

97 The discussion on global governance does, however, fuel the older debate on a possible world government. See recently for instance B.S. Chimni, 'International Institutions Today: An Imperial Global State in the Making', EJIL, 2004, pp. 1-37. 
bodies." ${ }^{\prime 98}$ The focus in the global administrative law project is on the administrative components and functions of international and transnational regulatory regimes. At the same time, however, quite a broad scope is adopted as "much of global governance can be understood and analyzed as administrative action: rule making, administrative adjudication between competing interests, and other forms of regulatory and administrative decisions and management." ${ }^{\text {99 }}$ The project thus addresses many of the questions posed in the present contribution with a view to a possible emergence of global administrative law. In doing so, many contributions focus on specific regulatory regimes, ranging from the OECD to accounting, the global garment industry, investment treaty arbitration, procurement rules, urban water service delivery, development co-operation, the environment, or the UNHCR. ${ }^{100}$ At the same time, contributions draw a comparison with domestic administrative law systems. ${ }^{101}$ The domestic analogy flows from the fact that the "real addressees of [...] global regulatory regimes are now increasingly the same as in domestic law: namely, individuals [...], and collective entities in regulated spheres including corporations and in some cases NGOs". ${ }^{102}$ This calls for the recognition of a global administrative space in which international and transnational administrative bodies interact in complex ways. The notion that this global administrative space can be distinguished from both the space of inter-state relations governed by international law and from the domestic regulatory space governed by domestic administrative law is underlined by the findings in the present contribution in relation

98 B. Kingsbury, N. Krisch and R.B. Stewart, 'The Emergence of Global Administrative Law', IILJ Working Paper, Vol. 1 2004, available at http://www.iilj.org/global_adlaw/, p. 5; also published in Law and Contemporary Problems, Vol. 3 \& 4 2005, pp. 15-62.

$99 \quad$ Ibid., p. 5.

100 For an extensive overview see the Global Administrative Law Bibliography available at http://www.iilj.org/global_adlaw/ as well as the special issues of the EJIL on Global Governance and Global Administrative Law in the International Legal Order, Vol. 1 2006; Law and Contemporary Problems, Vol. 3 \& 4 2005; and the NYU Journal of International law and Politics, No. 4. 2005. For the relevance to environmental law see: D.-Th. Avgerinopoulou, 'The Rise of Global Environmental Administrative Law - Improving Implementation and Compliance through the Means of Global Governance', Proceedings of the 7th International Conference on Environmental Compliance and Enforcement (INECE), 9-15 April 2005, Marrakech, Morocco, available at http://www.inece.org/ conference/7/vol1/21_Avgerinopoulou.pdf.

101 See for instance R.B. Stewart, 'U.S. Administrative Law: A Model for Global Administrative Law', IILJ Working Paper 2005/7, available at http://www.iilj.org/global_adlaw/. In this contribution we leave aside the consequences of globalisation for national administrative law as a result of the changing role of the State due to both the increasing interplay between national and international law and between the public and private sector. On this topic see for instance: A.C. Aman, Administrative Law in a Global Context, Ithaca: Cornell University Press, 1992; A.C. Aman, 'Administrative Law for a New Century', in: M. Taggert, (ed.), The Province of Administrative Law, Oxford: Hart Publishing, 1997; and J. Delbrück, 'Globalization of Law, Politics and Markets - Implications for Domestic Law - A European Perspective', Ind. J. Global Legal Studies, 1993, p. 9. For the consequences of the constitutional order of (in this case) the United States: M. Tushnet, The New Constitutional Order, 2003, Princeton: Princeton University Press, Ch. 5: Globalization and the New Constitutional Order.

B. Kingsbury, N. Krisch and R.B. Stewart, (see supra n. 97), p. 10. 
to multilevel regulation. In fact, one may state that nowadays the term 'global law' better represents the characteristics of the international (global) legal order than 'international law'. ${ }^{103}$

\subsection{Fragmentation}

The discussions of the 'fragmentation of international law' took a high flight at the end of the $20^{\text {th }}$ and the beginning of the $21^{\text {st }}$ century. The International Law Commission considered the issue serious enough to be taken up and its study group dealing with this matter recently issued a report on the matter. ${ }^{104}$ A great variety of scholars have meanwhile written on the phenomenon of the fragmentation of international law. ${ }^{105}$ The name refers to the increasing multitude of regulatory regimes and international dispute settlement systems, the jurisdiction of which may be partly overlapping or at least in conflict with other specialized fields of

103 Cf. also D. Lewis, (ed.), Global Governance and the Quest of Justice. Volume I: International and Regional Organizations, Oxford: Hart Publishers, 2006. That this could also be seen as a step towards a 'world government' was recently argued by B.S. Chimni, (see supra n. 96).

104 Report of the Work of the Study Group of the International Law Commission, finalized by Martti Koskenniemi, A/CN.4/L.682, 18 July 2006.

105 The literature on this subject abounds. See inter alia Canadian Council on International Law, Fragmentation: Diversification and Expansion of International Law : Proceedings of the 34th Annual Conference of the Canadian Council of International Law, Ottawa, Canadian Council on International Law 2006; M. Craven, 'Unity, Diversity and Fragmentation of International Law', The Finnish Yearbook of International Law, 2003, pp. 3-34; A. Del Vecchio, Giurisdizione internazionale e globalizzazione: i tribunali internazionali tra globalizzazione e frammentazione, Milan, Giuffrè, 2003; A. Fischer-Lescano and G. Teubner, 'Regime-Collisions: the Vain Search for Legal Unity in the Fragmentation of Global Law', Michigan Journal of International Law, 2004, pp. 999-1046; A. Gattini, 'Un regard procédural sur la fragmentation du droit international', Revue générale de droit international publique, 2006, pp. 303-336; G. Hafner, 'Pros and Cons Ensuing from Fragmentation of International Law', Michigan Journal of International Law, 2004, pp. 849-863; R. Huese Vinaixa and K. Wellens, (eds.), L'influence des sources sur l'unité et la fragmentation du droit international, Brussels, Bruylant, 2006; M. Koskenniemi, 'Fragmentation of International Law? Postmodern Anxieties', Leiden Journal of International Law, 2002, pp. 553-579; J. Pauwelyn, 'Bridging Fragmentation and Unity: International Law as a Universe of Inter-Connected Islands', Michigan Journal of International Law, 2004, pp. 903-916; E.-U. Petersmann, 'Justice as Conflict Resolution: Proliferation, Fragmentation and Decentralisation of Dispute Settlement in International Trade Law', University of Pennsylvania Journal of International Economic Law, 2006, pp. 273-366; M. Prost and P. Kingsley Clark, 'Unity, Diversity and Fragmentation of International Law: How Much Does the Multiplication of International Organizations Really Matter?', Chinese Journal of International Law, 2006, pp. 641-370; P. Rao, 'Multiple International Judicial Forums: A Reflection of the Growing Strength of International Law or its Fragmentation', Michigan Journal of International Law, 2004, pp. 929-961; S. Salinas Alcega and C. Tirado Robles, (eds.), Adaptabilidad y Fragmentacion del Derecho Internacional: la Crisis da la Sectorialización, Zaragoza, Real Instituto de Estudios Europeos, 1999; B. Simma, 'Fragmentation in a Positive Light', Michigan Journal of International Law, 2004, pp. 849-863; T. Stephens, 'Multiple International Courts and the "Fragmentation of International Environmental Law", Australian Yearbook of International Law, 2004, pp. 227-271; T. Treves, 'Judicial Law-Making in an Era of "Proliferation" of International Courts and Tribunals: Development or Fragmentation of International Law?', in: R. Wolfrum and V. Röben, pp. 587-620; K. Wellens, 'Fragmentation of International Law and Establishing an Accountability Regime for International Organizations: the Role of the Judiciary in Closing the Gap', Michigan Journal of International Law, 2004, pp. 1159-1181. 
international law and policy. Although the notion of fragmentation is also closely connected to an international regulatory order in which "an ever-increasing number of regulatory institutions with overlapping jurisdictions compete for influence", ${ }^{106}$ the scholarly research on this phenomenon is mainly conducted at a horizontal and global level. The fragmentation debate focuses on possible or real inconsistencies and conflicts between the various international regulatory regimes and dispute settlement mechanisms. It does not therefore specifically consider the legal and political consequences of multilevel governance and regulatory activities, as is the case in this contribution.

This having been said, the fragmentation debate provides us with valuable insights as far as the problem of conflicting norms is concerned. The aforementioned report of the study group on fragmentation of the International Law Commission addresses this problem, which it sees as a normal result of the development of "new rules and legal regimes as responses to new preferences, and sometimes out of conscious effort to deviate from preferences that existed under old regimes". ${ }^{107}$ One of the general conclusions of the report is that there is "no homogenous, hierarchical metasystem realistically available to do away with such problems [of coordination at the international level]". ${ }^{108}$ Therefore, "increasing attention will have to be given to the collision of norms and regimes and the rules, methods and techniques for dealing with such collisions". ${ }^{109}$ The report notes that further attention needs to be paid to these methods and techniques. The use of conflict clauses may be one technique, but these clauses are often unclear and ambivalent. Furthermore, conflict rules like lex posterior and lex specialis may need further study and may be insufficiently sophisticated to address the conflicts that can occur in the present international legal order. ${ }^{110}$

If the ordinary conflict rules are already inadequate in the present international legal order, this applies a fortiori to multilevel regulation: the rules of international treaty law on the relationship between various treaties are not adjusted to the complex

106 E. Benvenisti and G.W. Downs, 'The Empire's New Clothes: Political Economy and the Fragmentation of International Law', Stanford Law Review, 2007 (forthcoming, available at http://ssrn.com/abstract $=976930$ ).

107 Report of the Work of the Study Group of the International Law Commission, para. 484.

108 Ibid., para. 493.

109 Ibid.

110 For an illustration, examining the compatibility between WTO law and the new Unesco Convention on the Protection and Promotion of the Diversity of Cultural Expressions, see J. Wouters and B. De Meester, 'The Unesco Convention on Cultural Diversity and WTO Law: A Case-Study in Fragmentation of International Law', forthcoming in: Journal of World Trade, Vol. 42(1) 2008. 
interactions between global, macro-regional and domestic legal systems. Rather, one could hold with Fischer-Lescano and Teubner that

"[...] the unity of global law is no longer structure-based, as in the case of the Nation-State, within institutionally secured normative consistency; but is rather process-based, deriving simply from the modes of connection between legal operations, which transfer binding legality between even highly heterogeneous legal orders". ${ }^{111}$

\section{An Agenda for Research}

The phenomenon of multilevel regulation has thus been approached from a variety of angles, using a variety of concepts and terms. The 'invasion by international organizations' raises a number of new research questions which go beyond the law of international organizations itself and include EU and national law. It is above all the interplay between the legal orders that causes legal research to re-assess classic notions surrounding the hierarchy of norms, legal protection, judicial interplay and the normative force of international decisions. In doing so, legal scholars increasingly make use of notions and insights that were developed in other academic disciplines, notably political science and public administration. Below we have made an attempt to list some of the approaches which seem relevant in setting up an agenda for research related to the consequences of multilevel regulation.

\subsection{Combining Different Legal Perspectives: Accountability, Democracy, Legitimacy, Rule of Law}

An interesting contribution to the study of multilevel regulation, in line with the global administrative law project outlined above (supra, 3.2.), could be the emphasis on the need to rethink domestically based notions of democracy, legitimacy and the rule of law. After all, "[e]very European system acknowledges the primary function of administrative law as being the control of public power", ${ }^{112}$ or "bounded government". ${ }^{113}$ Harlow lists a number of principles as forming the basis for administrative law: accountability, transparency and access to information, participation, the right of access to an independent court, due process rights, including the right to be heard and the right to reasoned decisions and reasonableness. European legal systems have added proportionality and legitimate

\footnotetext{
111 A. Fischer-Lescano and G. Teubner, 'Regime-Collisions: The Vain Search for Legal Unity in the Fragmentation of Global Law,' Michigan Journal of International Law, 2004, pp. 999-1046.

112 C. Harlow, 'Global Administrative Law: The Quest for Principles and Values', EJIL, 2006, pp. 187-214, at p. 191.

113 M. Shapiro, 'Administrative Law Unbounded: Reflections of Government and Governance', Ind.

J. Global Legal Studies, 2001, pp. 369-377.
} 
expectations to this list. This calls for a linking of procedural and substantive norms. $^{114}$

We submit that a further conceptual refinement and extensive comparative research into these concepts and principles should be high on the research agenda. In this context, it is particularly the subject of accountability that seems to us to be of major importance, since it feeds back into issues of legitimacy and democracy. ${ }^{115}$ Little is known about accountability systems in international organisations and the similarities and differences between international organisations inter se and between them and national agencies. ${ }^{116}$ Even less research has been conducted on accountability in other international bodies and forums. Especially crucial issues - such as control over executive decisions, leadership selection mechanisms, control over the formulation of strategic and operational goals of international organizations and control over standard-setting competences - are in need of further investigation and analysis. With regard to the latter, more research should be devoted to the question of what regulatory standards should be focused on by different levels of governance and actors in the policy arena (standards of physical design, standards of performance or organisational decision procedures).

The aforementioned research, albeit legal in nature, can contribute to a more comprehensive analysis of the quality of regulatory work by international organisations and bodies (including the use of regulatory tools designed to achieve better regulation, such as regulatory impact assessments) and an assessment of the concept of (international) rule precision. Colin S. Diver ${ }^{117}$ distinguished three qualities of regulatory rules, namely transparency, accessibility and congruence, and has developed criteria to determine the appropriate degree of regulatory precision. An assessment of international rules from this perspective could contribute to a better understanding of the impact of international rules on lower levels of regulation.

114 Arguments against decoupling institutional, procedural, law from substantive law may for instance be found in B.S. Chimni, "Cooption and Resistance: Two Faces of Global Administrative Law', IILJ Working Paper 2005/16, available at http://www/iilj.org.

115 C. Graham, 'Is there a Crisis in Regulatory Accountability', in: R. Baldwin, et al., (eds.), A Reader on Regulation, Oxford: Oxford University Press, 1998, pp. 482-522.

116 With regard to the EU see D. Curtin, 'Holding (Quasi-) Autonomous EU Administrative Actors to Public Account', European Law Journal, 2007, pp. 523-541.

117 C. Diver, 'The Optimal Precision of Administrative Rules', in, Yale Law Journal, Vol. 93 1983, pp. 65-109. 


\subsection{A Public Policy Perspective on Multilevel Regulation}

A second set of questions that is assuming increasing importance with regard to multilevel regulation concerns the evaluation of these multilevel regulatory interventions from a public policy perspective. ${ }^{118}$ In assessing multilevel regulation from a public policy perspective, several theoretical arguments have been developed related to its possible benefits and drawbacks. Many of these arguments need further investigation. For example, some authors argue that dispersion of governance and regulatory practices across multiple jurisdictions is more flexible than the concentration of governance in one jurisdiction. This allows decision makers to adjust to diversity, reflect heterogeneity and stimulate competitive standard-setting dynamics. ${ }^{119}$ These arguments are closely related to the evolution from government to governance discussed above (supra, 2.2.). Identified drawbacks of multilevel regulation include incomplete information, inter-jurisdictional co-ordination, interestgroup capture and corruption due to ineffective systems of checks and balances. ${ }^{120}$ Most of these arguments about the drawbacks and benefits are, however, more hypotheses than established facts. Hence, more empirical research should focus on whether these claims are valid and, if so, under what conditions. Much of this research can build on existing studies that focus on intra-state dynamics or intraregional dynamics with regard to regulation. Let us briefly explore each aspect.

\subsection{Rule Dynamics, Co-ordination and Co-operation in Multilevel Regulation}

First, with regard to the issue of the beneficial consequences of flexibility and competitive dynamics in regulatory standard setting, research can build on existing studies that focus on lowest common denominator outcomes in collaborative standard setting. Some authors, in the context of international environmental policy making, have argued that the fears of lowest common denominator outcomes ('race to the bottom') are sometimes unwarranted in international collaborative standard setting and that under certain conditions a 'race to the top' can occur. ${ }^{121}$ In this

\footnotetext{
118 E. Ostrom, 'Institutional Rational Choice: An Assessment of the Institutional Analysis and Development Framework', in: P. Sabatier (ed.), Theories of the Policy Process, Oxford: Westview Press, 1999, pp. 35-72.

119 L. Hooghe and G. Marks, 'Unraveling the Central State but How? Types of Multilevel Governance', in: American Political Science Review, Vol. 97(2) 2003, pp. 233-243, especially pp. 235-236.

120 Ibid., especially p. 236

121 D. Esty and D. Geradin, (eds.), Regulatory Competition and Economic Integration: Comparative Perspectives, Oxford: Oxford University Press, 2001; J. Swinnen, (ed.), Global Supply Chains, Standards and the Poor: How the Globalization of Food Systems and Standards Affects Rural Development and Poverty, Leuven: CABI Publishing, 2007.
} 
context, other authors have pointed to the problem of being stuck at the bottom and the inability and/or reluctance of weak actors to participate in dynamic, co-operative standard setting initiatives. ${ }^{122}$ Most research in this context has been conducted on environmental or pollution control standards. ${ }^{123}$ This line of research can be extended to other areas, including pharmaceuticals, banking and aviation. ${ }^{124}$ Additional research should focus more on the dynamics of multilevel regulation at the international and national levels. A dynamic research perspective on standard setting should focus on questions related to the emergence of new rules (lowest common denominators), the development of new and existing related rules (convergence versus divergence; upward or downward dynamics) and the impact of these rules (implementation and effectiveness of rules).

Secondly, with regard to possible drawbacks, several issues need further investigation. The issues of imperfect information and inter-jurisdictional coordination are best placed in the overall context of co-ordination and co-operation problems in policy making. With regard to co-ordination problems, game theorists, institutional economists and political scientists have devoted much attention to the issue (and sometimes dilemma of) co-ordination. ${ }^{125}$ Multilevel regulation further extends and complicates this issue. As Hooghe and Marks observe, the coordination and transaction costs increase exponentially as the number of relevant jurisdictions increases. ${ }^{126}$ Several strategies can be followed to deal with the problem of co-ordination. The most prominent one is to limit the number of autonomous actors who have to be co-ordinated. ${ }^{127}$ Reducing the number of actors can be done via pooling actors in core groups or by excluding actors from negotiations on rules. The first is increasingly happening and research should focus on the issue of international core group formation, ${ }^{128}$ comparing different multilevel policy arenas in this respect.

\footnotetext{
122 G. Porter, "Trade Competition and Pollution Standards: "Race to the Bottom" or "Stuck at the Bottom"?', The Journal of Environment and Development, Vol. 8(2) 1999, pp. 133-151.

123 G. Spaargaren, A.P.J. Mol and H. Bruyninckx, 'Introduction: Governing Environmental Flows in Global Modernity', in: G. Spaargaren, et al., (eds.), Governing Environmental Flows Global Challenges to Social Theory, Massachutes: MIT Press, 2006, pp. 1-39.

124 See Follesdal, Wessel and Wouters (eds.), op.cit.

125 M. Olson, The Logic of Collective Action: Public Goods and the Theory of Groups, Harvard: Harvard University Press, 1965; E. Ostrom, Understanding Institutional Diversity, Princeton: Princeton University Press, 2005.

126 L. Hooghe and G. Marks, (see supra n. 118), pp. 233-243, especially p. 239. See also F. Scharpf, Games Real Actors Play. Actor-Centered Institutionalism in Policy Research, Boulder: Westview Press, 1997.

$127 \quad$ Ibid., especially p. 239 actor in WTO trade negotiations. The issue of core group formation is gaining ground in the EU
} 
The latter strategy - excluding actors - can generate problems of co-operation. In his classic work "Exit, Voice and Loyalty. Responses to Decline in Firms, Organisations and States", Hirschman introduced two types of responses or strategies related to problems arising in collaborative settings, namely exit or voice. Exit occurs when an actor's response to problems with other actors is to withdraw. Voice occurs when an actor's response to problems with other actors is to work with the other actors until the problem is corrected. An interesting question about multilevel regulation is which strategy is used by actors in different multilevel policy arenas. Secondly, research can focus on explaining differences in the use of these strategies. Especially interesting in this context is linking the use of strategies to the design of multilevel governance institutions with regard to the design of co-ordination procedures. For example, in the context of international automobile firms, Helper found that firms used different strategies (exit/voice) towards suppliers (other actors). This was partially explained by the degree of administrative co-ordination that existed between parties. Administrative co-ordination, in essence, referred to the nature and amount of information that flowed between actors. ${ }^{129}$ As a result, depending on the design of co-ordination infrastructure (supra) multilevel regulation might nurture exit or voice strategies. In other words, the interrelated issues of coordination and co-operation deserve special research attention in the context of multilevel governance.

\subsection{Accountability, Democracy and Social Justice in Multilevel Regulation}

Another set of issues, related to possible drawbacks of multilevel regulation, draws attention to issues related to accountability; and ultimately democracy and the ability of States to govern according to autonomously chosen, fundamental principles of governance (e.g. on issues of social justice and culture).

With regard to accountability, a crucial issue for research concerns the question of who is held responsible for actions and by whom. In a recent review article Bovens defined accountability as "a relationship between an actor and a forum, in which the actor has an obligation to explain and to justify his or her conduct, the forum can pose questions and pass judgement, and the actor may face consequences." ${ }^{130}$ This

itself, too. On this see S. Keukeleire, 'EU Core Groups. Specialisation and Division of Labour in EU Foreign Policy', CEPS Working Document, No. 252, 2006.

129 S. Helper, 'Strategy and Irreversibility in Supplier Relations - The Case of the United States Automobile Industry', Business History Review, Vol. 65(4) 1991, pp. 781-824.

130 M. Bovens, 'Analysing and Assessing Accountability: A Conceptual Framework', European Law Journal, Vol. 13(4) 2007, pp. 447-468, at p. 450 
definition builds on a principal-agent approach to accountability and highlights this important challenge to research on multilevel governance. ${ }^{131}$ In a simple principalagent model an agent reports directly to the principal who delegated to the agent the freedom to act on his/her behalf. However, as Benz, Harlow and Papadopoulos stress, systems of multilevel governance do not easily fit into this conceptual framework. "By complicating and obscuring straightforward 'chains of delegation' [...] they make it hard to identify a principal." ${ }^{132}$ The latter, the identification of principals in multilevel systems, constitutes a major research topic for scholars studying international organisations. Comparative research designs might highlight striking differences between and within international organisations across policy domains/arenas.

The issue of accountability feeds into the issue of democracy and democratic control of multilevel governance. The issue of democracy poses another challenge: research needs to be conducted into the underlying models of democracy that underpin multilevel governance. ${ }^{133}$ It is important that this type of research focuses not only on a comparison of multilevel regulation arrangements vis-à-vis normative ideal types of democracy, but also takes into account the day-to-day reality of democracy. As Moravcsik argues, with regard to the democratic deficit debate in the European Union, purely philosophical assessments can be interesting but run the danger of narrowing down conceptions of democracy:

"Comparisons are drawn between the EU and an ancient, Westminster-style or frankly utopian form of deliberative democracy. While perhaps useful for philosophical purposes, the use of idealistic standards no modern government can meet obscures the social context of contemporary European policy-making - the real-world practices of existing governments and the multilevel political system in which they act. This leads many analysts to overlook the extent to which delegation and insulation are widespread trends in modern democracies, which must be acknowledged on their own terms. The fact that governments delegate to bodies such as constitutional courts, central banks, regulatory agencies, criminal prosecutors, and insulated executive negotiators is a fact of life, one with a great deal of normative and pragmatic justification." ${ }^{134}$

Besides models of democracy underpinning multilevel governance, a related set of questions points to the issue of what models of social justice and cultural diversity

131 D. Hawkins, D. Lake, D. Nielson and M. Tierney, Delegation and Agency in International Organizations, Cambridge: Cambridge University Press, 2006.

132 A. Benz, C. Harlow and Y. Papadopoulos, 'Introduction', European Law Journal, Vol. 13(4) 2007, pp. 441-446, at p. 444; Special Issue: Accountability in EU Multilevel Governance, edited by: Arthur Benz, Carol Harlow and Yannis Papadopoulos.

133 D. Held, Models of Democracy 2nd Edition, Cambridge U.K.: Polity Press, 1997.

134 A. Moravcsik, 'In Defense of the Democratic Deficit: Reassessing Legitimacy in the European Union', Journal of Common Market Studies, Vol. 40(4) 2002, pp. 603-624, especially pp. 605606. 
are incorporated in international rules. In the context of social justice models it is important to assess whether international rulemaking follows standard economic optimisation rules or includes more egalitarian perspectives. The analysis of social justice models embedded in policy making and governance

structures at the level of the nation State has a very long tradition. ${ }^{135}$ In the context of the EU, too, some attention has been paid to this topic in the context of the debate on the European social model. Issues of convergence or divergence between governance structures promoting market efficiencies vis-à-vis governance structures promoting social protection and equality have been analysed. ${ }^{136}$ However, less research is being conducted on what models of justice are incorporated, implicitly and explicitly, in international rule making and what the effect is on national models of justice. This requires an assessment of the redistributional equity principal in international policy making (who pays, who gains and what compensating measures are in place). For example, international rules on pharmaceuticals might stipulate the degrees of freedom for national healthcare policies with regard to medication and in this way feed back into policies closely related to social protection and redistributive sensitivities. Finally, in a globalising context, a cultural assessment - i.e. the conformity of rules to general morality within different countries - becomes increasingly important. The late Clifford Geertz ${ }^{137}$ highlighted the importance of the cultural context in which rules are made and implemented. As a result, problems arising from a mismatch between international rules and cultural norms need further investigation.

\section{CONCLUDING OBSERVATIONS}

The phenomenon of multilevel regulatory processes and, more particularly, the various interactions between global, EU and national levels of policy and rule making are gradually becoming recognised in both the legal and political scientific communities. However, knowledge remains scattered, fragmentary and in many cases punctual or even anecdotal. There is clearly a need for a more comprehensive, thorough analysis of multilevel regulation and its ramifications. In the

135 G. Esping-Andersen, The Three Worlds of Welfare Capitalism, Cambridge: Polity Press and Princeton: Princeton University Press, 1990. G. Esping-Andersen, D. Gallie, A. Hemerijck and J. Myles, Why We Need a New Welfare State (with D. Gallie, A. Hemerijck and J. Myles), Oxford: Oxford University Press, 2003.

136 F. Scharpf, 'The European Social Model: Coping with the Challenges of Diversity', Journal of Common Market Studies, Vol. 40(4) 2002, pp. 645-670.

137 C. Geertz, Local Knowledge: Further Essays in Interpretive Anthropology, London: Fontana Press, 1993. 
present contribution we have both tried to identify and sketch the phenomenon with a variety of illustrations, go through the responses of legal scholarship thus far, and set out an agenda for further research, including both legal and non-legal approaches. One thing seems certain: we are confronted with an arena with plentiful, rich themes for interdisciplinary research for many years to come. Faced with multilevel regulation, the old categories and dividing lines between international, European and national legal orders no longer work satisfactorily and there is a clear need to rethink concepts such as transparency, democratic control of regulatory power, legitimacy, rule of law and judicial protection of fundamental human rights in situations of governance beyond the state. 


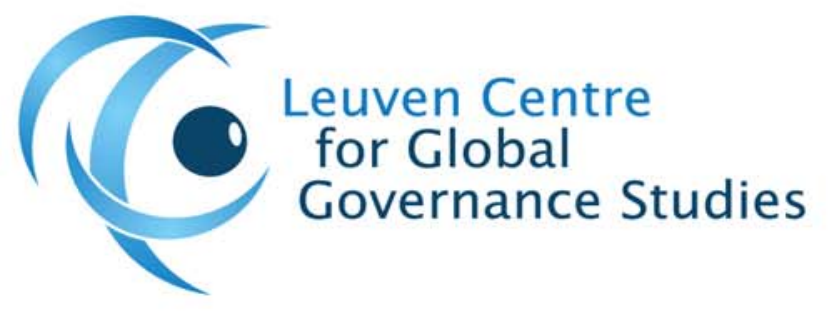

The Leuven Centre for Global Governance Studies is an interdisciplinary research centre of the Humanities and Social Sciences at the Katholieke Universiteit Leuven. It was set up in the Spring of 2007 to promote, support and carry out high-quality international, innovative and interdisciplinary research on global governance. In addition to its fundamental research activities the Centre carries out independent applied research and offers innovative policy advice and solutions to policy-makers on multilateral governance and global public policy issues.

The Centre brings together talent from throughout the University. It operates on the basis of co-ownership and the strong conviction that interdisciplinary research creates added value to resolve complex multi-faceted international problems. The Centre promotes pioneering projects in law, economics and political science and actively initiates and encourages interdisciplinary, cross-cutting research initiatives in pursuit of solutions to real world problems. The cross-cutting initiatives are thematic projects around which University researchers join forces across disciplines to forge responses to complex global challenges. The cross-cutting initiatives address critical issues in relation to globalization, governance processes and multilateralism, with a particular focus on the following areas: (i) the European Union and global multilateral governance; (ii) trade and sustainable development; (iii) peace and security, including conflict prevention, crisis management and peacebuilding; (iv) human rights, democracy and rule of law.

In full recognition of the complex issues involved, the Centre approaches global governance from a multilevel and multi-actor perspective. The multi-level governance perspective takes the interactions between the various levels of governance (international, European, national, subnational, local) into account, with a particular emphasis on the multifaceted interactions between the United Nations System, the World Trade Organization, the European Union and other regional organizations/actors in global multilateral governance. The multi-actors perspective pertains to the roles and interactions of various actors at different governance levels, these include public authorities, non-governmental organizations and private actors such as corporations.

For more information, please visit the website www.globalgovernancestudies.eu

Leuven Centre for Global Governance Studies

Europahuis, Blijde Inkomststraat 5, 3000 Leuven, Belgium

Tel. ++32 $16328725 \quad$ Fax ++32 16328726

info@ggs.kuleuven.be

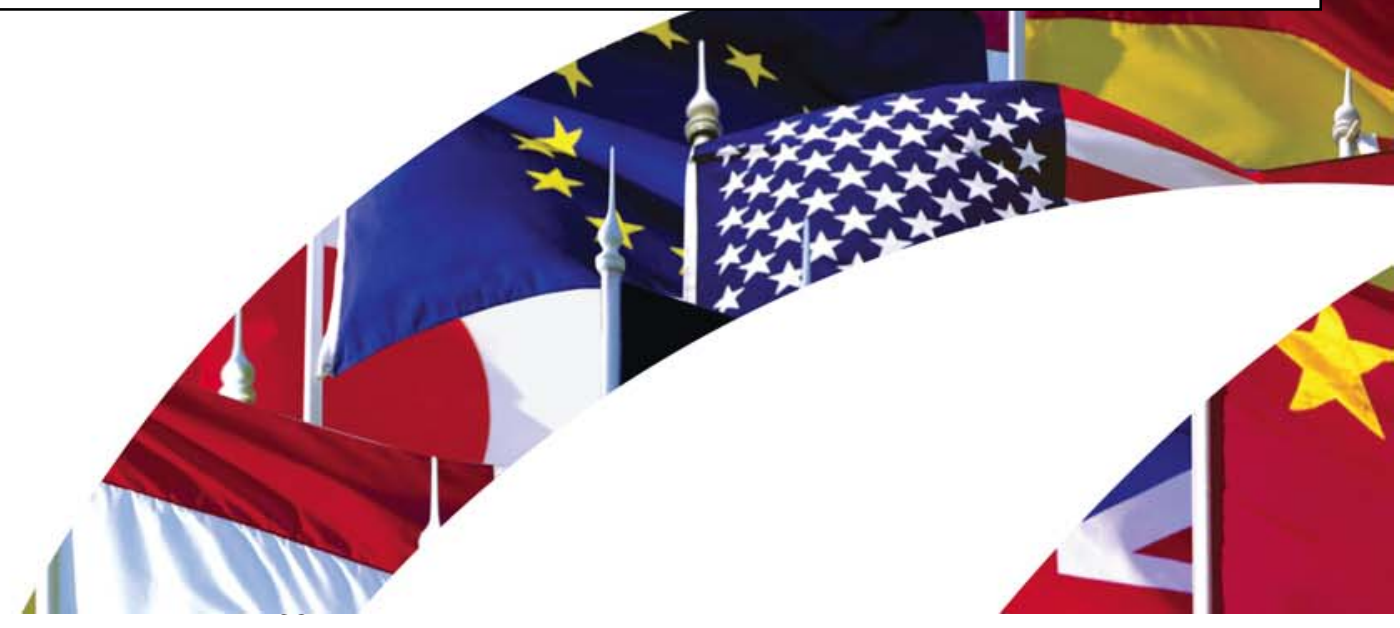

